\title{
Can the Welfare State Replace Parents? Children's Cognition in the United States and Great Britain*
}

\author{
Toby L. Parcel
}

\author{
and \\ Lori Ann Campbell
}

(C) 2016. This manuscript version is made available under the Elsevier user license http://www.elsevier.com/open-access/userlicense/1.0/ 


\section{CAN THE WELFARE STATE REPLACE PARENTS? CHILDREN'S COGNITION IN THE UNITED STATES AND GREAT BRITAIN}

In recent years we have learned a great deal about how families influence child outcomes in the United States (U.S.). We know that family social capital is important in promoting both child cognition and social adjustment (Dufur, Parcel and Troutman 2013; Dufur, Parcel and McCune 2008); that fathers play a vital role in promoting child wellbeing (Coltrane 1996; Marsiglio and Roy 2012); and that marital disruption can be detrimental to child and adolescent development (Amato 2010; Kim 2011). We know much less, however, about whether these same findings hold in countries outside the U.S., and whether similar processes are at work cross-culturally.

We address this deficit by studying the determinants of children's cognition in both the U.S. and Great Britain (G.B.). Classic sociological findings suggest that child cognition is important because it predicts school success, an important precursor of placement in western stratification systems (Crouse et al. 1979). Lower levels of cognition, even among younger children, are associated with subsequent reduced high school graduation rates, lower probabilities of college enrollment and lower levels of academic achievement (Jencks et al. 1979; Sewell and Hauser 1975). Thus, children's cognition has implications for long-term socioeconomic success.

More recently, Breen and Johnson Jonsson (2005) argue that while we know a fair amount about the common elements of social mobility across countries, data limitations often preclude deeper analysis of the micro-level underpinnings of what produces both similarities and differences cross culturally. There have been cross cultural studies in household time use, which do highlight the importance of welfare state differences 
underlying household division of labor. For example, in a study of time spent on child care in Austria, Denmark, Italy and France, Craig and Mullan (2011) find that the social welfare context influences the role of individual and household level characteristics in determining how much care mothers assume relative to fathers (see also Sayer and Gornick 2012; Treas and Drobnic 2010). These studies reinforce the need to analyze how welfare state differences may condition the role of parental characteristics in affecting child wellbeing directly.

In this analysis we take advantage of unique and comparable micro-level data produced in the early 1990 s to study how family characteristics place children on their paths within the stratification systems of the U. S. and G. B. We do this within the context of the possibility that macro-level differences in state welfare systems from that era may be associated with family characteristics, thus producing associations between welfare states and child pathways leading to adult socioeconomic status.

We consider whether the same processes are at work cross culturally for two types of cognitive outcomes. First we look at verbal facility, the ability of children to match pictures with words that they hear verbally. This is a measure that reflects pre-reading skills of young children and those older children still learning to read. Second, we look at tests of both reading and mathematics achievement, which are outcomes more proximate to letter grades in school and progression towards high school graduation and attainment in post-secondary schooling. By using three dependent variables, we develop a deeper picture as to whether welfare state differences may be conditioning family processes to produce these outcomes differently by society.

\subsection{WHY COMPARE SOCIAL PROCESSES ACROSS THE UNITED STATES}

\section{AND GREAT BRITAIN?}


Kikuzawa (2006) suggests we can deepen our understanding of the effects of institutions on individuals if we compare countries that are similar on some dimensions but different on others. McDonough, Worts and Sacker (2010:234) argue for a comparison of the U.S. and G.B. because historically both are minimally redistributive welfare states and both created welfare-to-work programs in the 1990s; however, the two societies are different because G.B. was more focused on poverty reduction. O'Connor, Orloff and Shaver (1999:18) also note similarities, but argue that even for these two liberal welfare states, there were important differences in benefits, taxation, and labor union strength during this era. They find variation in gender stratification and household decisions regarding market work for mothers across several such societies (O’Connor et al. 1999:225-26).

We extend these traditions here. Specifically, G.B. and the U.S. are similar in democratic forms of government and in levels of industrial development; children begin schooling at similar ages (5-6) and continue until at least the middle teen years (Kerckhoff 1990, 1993). The two societies share a common language and Western European heritage. However, their patterns of parental work are different and their welfare states provide differing levels of support to families. Our modeling also controls for differences in their educational systems.

There is a relative dearth of studies that compare micro-level processes investigating how families and their characteristics in G.B. and the U.S. may differently affect child cognition. Joshi et al. (1999) focus on divorce and find that selected family characteristics can mediate the influence of family disruption on children's cognitive development in both societies. McCulloch et al. (2000) document that non-two-parent family structures and family adversity predict lower levels of children's cognition in both 
countries. In addition, Michael (2003) takes a descriptive approach by studying the distributions of child cognitive outcomes between the U.S. and G.B. He finds the age distributions of test scores largely similar cross-culturally. However, similar distributions of scores by age do not tell us whether predictors of these scores are similar or different. Accordingly, our study takes a theoretically guided, analytical approach to studying capital effects on child cognition, while also placing the findings within the context of the two countries' different welfare state systems.

\subsection{WORK, FAMILY AND WELFARE STATES: COMPARING THE UNITED STATES AND GREAT BRITAIN}

Considerable literature comparing work, family and welfare in the U.S. and G.B. is descriptive. Ferber, O'Farrell and Allen (1991), a relevant source given the age of the data we will use, document that the U.S. offers fewer social welfare programs than many Western European countries including G.B. Key differences include supports to families with working adults who also care for children, such as maternity or family leaves and state-subsidized child care. G.B. spends a higher proportion of its Gross Domestic Product (GDP) on social welfare than the U.S., while the U.S. spends more on defense. Most important, in G.B., social welfare supports for maternity and family, disability, old age and death are universal, while in the U.S., these benefits are tied to employment (Gornick and Jacobs 1998). The recent U.S. passing of the Affordable Care Act obviously does not affect our analysis of data from the early 1990s.

Esping-Andersen (2002) argues that we need a new welfare state where there is greater investment in children and families, in part because investments in child wellbeing are cheaper and more effective than are later interventions in the life cycle, such as job training (Heckman 2008). Esping-Andersen argues that when societal investment is 
greater, such as in Scandinavian countries, family inputs should be less important determinants of child well-being than when social investment is lower (Esping-Andersen 2002:27). This is a key question with which societies struggle: how much investment should come from parents and how much from society generally? For example, in many European countries with strong welfare states, tertiary education at universities is provided free to students, thus relieving students' families of the burden of making that investment and preventing students from having to incur significant educational debt. Despite the importance of these arguments, Esping-Anderson does not test his hypotheses at the micro level.

\subsection{COMPARING PARENTAL WORK, FAMLY STRUCTURE, AND FAMILY SUPPORTS}

We know that family and parental work characteristics are important determinants of child cognition (Parcel and Menaghan 2994a, b). But parental work varies cross culturally. Maternal work in G.B. is disproportionately a part-time phenomenon, while in the U.S., maternal work is more often full-time, even for mothers of young children (Powell 1999). Although recent data suggest labor force participation rates for women are higher in G.B. than in the U.S., even currently maternal work in G.B. remains disproportionately part-time relative to maternal work the U.S. (Blau and Kahn 2013). Given that maternal work affects child cognition generally (Hsin and Felfe 2014; Parcel and Menaghan 1994a, b), it may differentially affect child cognition across the two societies, either because maternal work differs cross-culturally or because children obtain differential returns to it.

Family structure is another consequential factor affecting child well-being (McLanahan and Percheski, 2008; Brown 2004). Kamerman and Kahn (1997) document 
that by the 1990s, Great Britain's family structures began looking more like those in the U. S., in terms of increasing rates of cohabitation, divorce and re-marriage, as well as smaller family sizes. However, they note that divorce rates in the U.S. remained higher than those in G. B. during this period. Again, we investigate whether converging family structures have similar effects on child cognition.

A key societal difference is that the British welfare state provides greater levels of family supports than does that in the U.S. For example, in the U.S., the Family and Medical Leave Act was not enacted until 1993, and even then its provision of a guaranteed 12 weeks of family and/or medical leave was unpaid and did not apply to establishments with less than 50 employees, a major constraint for employed women. In contrast, in G.B., the 1975 Employment Protection Act guaranteed 29 weeks of leave following childbirth, of which 18 weeks was paid, as well as right of return to a similar job (Gregg, Gutierrez-Domenech, and Waldfogel 2003).

Similarly, family benefits in G.B. exceeded what was offered in the U.S. in the 1990s. G.B. offered means-tested as well as non-means tested allowances. The primary non-means tested allowance in effect during the 1990s was the universal "Child Benefit," which was a payment to those with dependent children, with an extra allowance available to single parents. In addition to these allowances were means-tested benefits for families with dependent children, provided that one parent was employed and additional support for single parents and those with disabilities (Kamerman and Khan 1997). The U.S. had no universal payment to families with dependent children, relying instead on a combination of tax-exemptions tied to employment and income and means-tested benefits for those families falling below the poverty level, also sometimes conditional on employment. 
Regarding child care, G.B. and the U.S. are similar in that there is no universal child care provided to all families with young children. In both countries, child care for very young children (under age 3 ) is handled by families through a combination of private services and information arrangements. For preschool-aged children, however, G.B. provides publicly-funded child care to families through its Local Educational Authorities (Kamerman and Khan 1997). In the U.S. there is no comparable publiclyfunded child care available to families with preschool-aged children, although some families with low incomes qualify for free child care through HeadStart. Finally, health care needs of families are met in G.B. through the National Health Services while in the U.S., access to health care was tied to employer-provided insurance or, for low-income families, Medicaid. In sum, the investments that G.B. makes in such things as family allowances and in universal health care relieve families of having to make these same investments, thus freeing family resources to cover other needs. This is in contrast to the U.S., where there is a strong ethic of individual responsibility.

\subsection{MICRO-LEVEL COMPARISONS OF THE UNITED STATES AND GREAT}

\section{BRITAIN}

There are a few recent comparisons between the U.S. and G. B. regarding the micro-level processes predicting two other dimensions of child well-being. Campbell and Parcel (2010) show that maternal education, maternal cognition, race, family size, and the risk factor of child male gender, as well as aspects of family structure, are equally important in the U.S. and G.B. in determining the strength of children's home environments, an important predictor of child cognition in the U. S. (Parcel and Menaghan 1994a, b). Parcel, Campbell and Zhong (2012) also demonstrate that children's home environments, health limitations, maternal divorce and child male gender 
are equally important in affecting the likelihood of children's behavior problems, an important aspect of child well-being and also a precursor of high school graduation and college enrollment in the U.S. (McLeod and Kaiser 2004). Remaining to be studied, however, are whether these characteristics of families and children are also similar across these societies in their effects on child cognition.

\subsection{ANALYZING CHILDREN'S COGNITION: THEORY, PAST RESEARCH}

\section{AND HYPOTHESES}

\subsection{THEORY: INVESTMENT PERSPECTIVES ON CHILD COGNITION}

We argue that three forms of investment are important in promoting child cognition. First, following Coleman (1990), we believe that social capital is essential in child socialization. Social capital, or relations among actors that "inhere in family relations and in community organization and that are useful for the cognitive or social development of a child or young person" (Coleman 1990:300), includes the time and effort that parents spend on children, which is reflected in the quality of home environments parents construct. Parental investments in age-appropriate cognitive stimulation, in affectively warm styles of interaction, and in safe home environments combine to promote higher levels of child cognition (Parcel and Menaghan 1994a, b).

Also, greater numbers of children in the family dilute the amount of time a parent can spend with each child (Coleman 1990; Downey 1995; Fogelman 1983). ${ }^{1}$ Coleman also argues that social capital is stronger in two-parent families, which have more resources with which to promote child well-being than do single-parent families (Amato 2010; Kim 2011). We also expect that mothers who were socialized in two-parent families will have a stronger base of social capital with which to promote well-being of their own children. That long parental work hours are negatively associated with child 
cognition (Parcel and Menaghan 1994a) is also compatible with concerns about the amount of social capital needed for effective parenting. Overtime work hours, or even maternal work itself, may limit both the quality time that parents spend with young children as well as the duration of parental-child interaction (Coleman 1990), although research has suggested this concern may be overgeneralized (Parcel and Menaghan 1994a, b).

Social norms are a form of social capital influential in promoting child cognition. Kohn and colleagues argue that parents create socialization environments according to the expectation they themselves confront on the job, under the implicit assumption that their children will occupy work roles similar to their own (Kohn and Schooler 1983; Kohn and Slomczynski 1990). Lareau (2011) finds that middle and working class parents use notably different socialization strategies, and that these differences are associated with differential academic achievement ten years later. Although Schaub (2010) finds that social class differentials in the frequency of reading to young children had disappeared by 1991, such activity is only one part of child socialization important for cognition. In sum, parents may use differing norms to guide child socialization, with these differing norms a partial function of parental occupation.

At the same time, two additional forms of capital are consequential. Families also contain financial capital, which is important in supporting child well-being. Material support is a foundation for family life (Duncan, Brooks-Gunn and Klebanov 1994; see Mayer 1997, for different arguments). Lower levels of material resources also cause parental distress, which threatens constructive parent-child interaction (Mirowsky and Ross 2003; Conger, Conger and Martin 2010). 
Similarly, higher levels of parental human capital are also consequential. Higher levels of parental education, greater cognitive skills, stronger investments in their own learning, and the opportunity to participate in a stronger academic track should promote child cognition (Parcel and Menaghan 1994a; see also Heckman 2008). More educated parents will communicate higher expectations for academic achievement, while higher levels of grandparents' education and occupations will provide more human and social capital for mothers as they promote cognition in their own children (Parcel and Menaghan 1994a, b, although see Warren and Hauser 1997). Finally, stronger expectations for maternal education while mothers were growing up suggests the transmission of intergenerational norms supporting achievement (Davis-Kean 2005). In addition, we expect that older mothers and older fathers will have more interpersonal resources with which to promote child cognition (Parcel and Menaghan 1994a, b).

Regarding child human capital, children who are of low birth weight or who have health problems may have more difficulty with academic tasks compared to healthier and normal birth-weight peers. Because boys lag behind girls developmentally, we are also alert for sex differences in cognition (Parcel and Dufur 2001; Parcel and Menaghan 1994a). We also control for race.

\subsection{SUMMARY OF HYPOTHESIZED EFFECTS}

These arguments suggest that our models should include measures of social, financial and human capital. The left-hand stub in Table 1 indicates the independent variables reflecting these concepts but arrayed in categories including child and parental background, family of origin, parental work and family structure, as well as child verbal facility (PPVT-R) that we use as a control in our estimates on child achievement. It also shows the expected signs of each coefficient predicting children's cognition. If capital at 
home is equally influential in G.B. and in the U.S., then the two data sets should show regression coefficients for the same variables that are similar in size. Such findings would indicate that parental, child and family characteristics are equally important across the two cultures in influencing child cognition. By extension, such findings would show that the stronger welfare state in G.B. was not a substitute for parental characteristics, thus conflicting with Esping-Anderson's argument.

If parental and family characteristics are more influential in G.B. than in the U.S., then the coefficients' sizes should be larger in analyses of the British compared with the U.S. data. Such findings would signal that families matter more in G.B. than in the U.S. in promoting cognition, perhaps reflecting stronger social class inheritance effects in G.B.. ${ }^{2}$ Finally, parental effects may be more important in the U.S. than in G.B. If so, then coefficient sizes should be larger for the U.S. data than for the British. If we observe these latter effects, the importance of social inheritance may have waned in G.B. and/or the British welfare state may be effectively substituting for some parental inputs. For example, divorce may be more detrimental to children in the U.S. than in G.B., where the welfare state may partly protect children from the effects of parental divorce. We also may find that some variables are more influential in the U. S. than in G.B., while for other variables the relationships are reversed. Such evidence would support the notion that welfare state effects on child cognition are inconsistent.

\subsection{DATA AND METHODS}

Our data are drawn from two longitudinal panel surveys: the National Longitudinal Survey of Youth's child-mother data set (hereafter NLSY79) and the National Child Development Study (hereafter NCDS or British Child). Our U.S. sample, the NLSY79, is a national probability sample of people born between 1957 and 1964. All 
children born to the female NLSY79 respondents were surveyed and included in the "Child Sample" of the NLYS79. Our British sample, the NCDS, included everyone born in Great Britain during the first week of March, 1958. All children born to nearly onethird of the 1958 respondents were surveyed as part of the "Child of the NCDS" study (Baker et al. 1993; NCDS Child and Parent Users' Data Guide 1998); these children were administered the same cognitive assessments as children born to the NLSY79 female respondents. For both samples, we refer to the original cohort as the parents and the offspring born to them as the children. In the NCDS, we limit our analysis to the children of the mothers so that our samples are as comparable as possible to the NLSY79 children.

\subsection{SAMPLES}

Our samples are drawn from the 1991 wave of the NCDS, when the mothers were age 33, and the 1994 wave of the NLSY79, when the mothers were 29-36. The ages of the mothers are the most comparable in these waves. The children in our sample are aged 5-13 years, which gives us the chance to use comparable measures of cognition across age groups in the NLSY79 and NCDS. In addition, children younger than five cannot be assessed reliably on many outcomes, and children older than thirteen were necessarily born when the mothers in our samples were very young, and thus may be atypical of children of that age more generally. ${ }^{3}$

In our British sample, there were 2,528 children born to NCDS female cohort members by 1991; there were 1,530 for whom we could positively identify their ages being 5-13; we eliminated 46 who were missing on birth-weight, as well as 121 missing on all cognition indicators. We eliminated a few remaining children $(\mathrm{N}=21)$ of very low birth weight, also likely to be atypical of children their ages. All these British children lived with their mothers who were cohort members from the original 1958 survey. Thus, 
there are 1,309 children of British mothers who had valid data for cognition in the 1991 survey and whom we study in this analysis. Hakim (2000:131) notes that over $80 \%$ of the original 1958 cohort was interviewed in 1991, with a slight bias towards losing lower SES respondents. These losses pose minimal risks to sample representativeness.

In our U.S. sample, there were 10,918 children born to NLSY79 female cohort members by 1994 . We selected the 4,435 children whom we could positively identify as being aged 5-13. Selecting only those living with their mothers left us with 4,087. We eliminated 37 with very low birth-weight, leaving 4,050. We further limit our analysis to 3,439 children with valid data on all of the cognitive assessments in 1994 .

\subsection{MEASURES}

The British Child survey was designed to replicate the survey of the children in the U.S. NLSY79, particularly the assessments of children. The key measures of children's home environments, verbal facility and academic achievement used in the

NLSY79 - Child surveys have been thoroughly studied and have high reliabilities and validities (Baker et al. 1993). Moreover, the numerous studies using data from the NLSY79 - Child provide further evidence regarding these measures' validities (NLS Handbook 1999). Thus, the British Child survey relies on these advantages.

For both the British and American samples, we used three measures of children's verbal facility and academic achievement. Children's verbal facility was measured with the Peabody Picture Vocabulary Test-Revised (PPVT-R, 1981), while the Peabody Individual Achievement Test was used to measure math and reading achievement. Below we describe each measure in greater detail (see Table 2 for measures of all variables).

\subsubsection{Peabody Picture Vocabulary Test-Revised (PPVT-R)}


The PPVT-R is a test of hearing vocabulary. It measures a child's understanding of spoken words and is among the most widely-used indicators of language acquisition and scholastic aptitude among children (Dunn and Dunn 1981). In this test, the interviewer speaks a word and the child chooses the picture that best describes the word's meaning (NLS Handbook 1999). Using a representative sample of children, scores are then normed to have a mean of 100 and a standard deviation of 15 . In our analyses, the mean standard score on the PPVT-R among American children was 90.21 with a standard deviation of 18.67 , while among British children the mean was 98.68 with a standard deviation of 15.46. That the sample mean among children in the U.S. was lower than that from the norming sample is not unusual given that economically disadvantaged children are overrepresented in the NLSY data (Baker, Keck, Mott, and Quinlan 1993; Guo 1998).

\subsubsection{The Peabody Individual Achievement Test-Reading and Math (PIAT-R and}

\section{PIAT-M)}

The Peabody Individual Achievement Test (PIAT) measures math and reading achievement among children ages five and older. The PIAT is one of the most highlyregarded assessments of academic achievement with high reliability and validity (The NLSY Children, 1992: Description and Evaluation). As with the PPVT-R, we use standard scores in all PIAT analyses. The PIAT math assessment consists of 84 multiple choice questions that gradually increase in difficulty. For young children, the test begins with recognizing numbers and proceeds to geometry and trigonometry concepts for older children. Among American children, the mean PIAT math score is 99.46 with a standard deviation of 13.32 , while the mean for British children is 106.78 with a standard deviation of 13.05. The PIAT reading recognition assessment measures the ability to read aloud. The assessment consists of 84 items of increasing difficulty for preschool-aged 
children through high school. In the sample of U.S. children, the mean PIAT reading score is 102.58 with a standard deviation of 14.61, while the mean for British children is 109.29 with a standard deviation of 15.28 .

\subsubsection{Measures of Independent Variables}

Measures of many variables were largely comparable across the two data sets, including sex of the child, birth weight and family size, maternal investment in learning, children's and parents' ages, and parental work hours. There are also some minor differences. NLSY79 mothers' 1980 Armed Forces Qualifying Test (AFQT) scores are similar to I.Q. test scores; we compare them to NCDS mothers' scores on the 1969 British Age 11 exams used to determine student placement in a secondary school. There is slightly more detail on the health problems of British children than for NLSY79 children (see Table 2).

We constructed the HOME scales to reflect cognitive, affective and physical aspects of children's home environments in both countries. Alpha reliabilities for the NCDS HOME scales were .61 for 5-year olds, and .69 and .76 for 6-9 year-olds and 10-13 year-olds, respectively. The alpha reliabilities for the NLSY79 HOME measures were .66 for 5 year olds, and .75 and .76 for the 6-9 year-olds and the $10-13$ year-olds, respectively. Campbell and Parcel (2010) provide additional details regarding the HOME measures and scale construction.

Measures reflecting schooling and occupations in G.B. vary from those in the NLSY79. Measures reflecting school track for the British Child reflect the British system of schooling during the 1960 s, which was a period of change as the British educational system moved away from a rigidly stratified school system toward comprehensive schools for students of all abilities without selection. In 1965 when the parental cohort 
was 7 years old, only $4 \%$ of students attended comprehensive schools; $22 \%$ were enrolled in the academically elite grammar schools, while a majority of students $(64 \%)$, who did not perform as well on the Age 11 exams and would not attend university, went to secondary modern schools (Jesson 2000). ${ }^{4}$ A decade later, when the parental cohort was age 17 , approximately $57 \%$ of British students attended comprehensive schools; $12 \%$ were enrolled in the grammar schools and $27 \%$ went to secondary modern schools (Jesson 2000).

The occupational dummies follow a traditional hierarchy, with differences between the categories used for the cohort member as compared with their fathers (the grandfathers), because there were changes in the distributions of occupations over time. For example, $65 \%$ of the grandfathers occupied manual positions, while less than $7 \%$ of cohort members were in skilled manual slots.

Table 3 shows means and standard deviations of the variables used in the analysis. When variables were measured the same in both samples, we performed tests of statistical significance to determine whether the countries differed in levels of these variables.

\subsection{MISSING DATA AND CORRECTION FOR CLUSTER SAMPLING}

The NCDS data set has missing data on several variables. ${ }^{5}$ We use data from prior waves of the NCDS data set to fill in the same data subsequently missing, including for grandparents' occupations, family structure and parental work hours (see Powell 1999). For remaining variables, following Allison (2002) we used a data augmentation approach to estimate a multiple imputation procedure using SAS, which relies on a sequential chain of data augmentation cycles (see also Little and Rubin 2002). Using a series of ten regression models, i.e., ten imputations, to predict the missing values of independent 
variables, the procedure estimates a set of plausible values for missing data and replaces the missing values with these estimates and produces appropriate standard errors. The estimates are analyzed using standard regression procedures, and then results from these analyses are combined. The resulting estimates reflect statistically valid inferences that take into account the uncertainty owing to missing values (Allison 2002). We used these same procedures on the NLSY79 data, although the proportions of missing data were lower.

Approximately 30 percent of the families in the NCDS and 38 percent of the families in the NLSY79 had more than one child per family in our sample, which results in correlated errors within families. We use the SAS cluster procedure to correct for these within family groupings. This strategy preserves numbers of cases while still correcting for the clustering effects on the standard errors. Finally, to address possible multicollinearity, we inspected collinearity diagnostics. For significant variables, all of the variance inflation factors were below 3.5; the standard errors did not fluctuate substantially (Fox 1991).

\subsection{PLAN OF ANALYSIS}

We estimate three regression models each for the U.S. and British samples. Much of the literature on the academic achievement of children finds that the characteristics of parents and children themselves predict child cognition. Thus, our first model includes child and parental background characteristics. Our second model draws upon work socialization theories and incorporates variables related to parental employment and income. Our third model includes family structure and size, as well as the quality of children's home environments. For PIAT-Reading and PIAT-Mathematics, we introduce PPVT-R as a final control to allow inferences regarding whether background 
characteristics provide both indirect as well as direct effects on these outcomes. For ease in presentation, we do not display coefficients associated with grandparents and parental occupations. ${ }^{6}$

To determine whether there were differences across countries, when the unstandardized coefficients were significant in the U.S., G.B., or in both samples, and the variables were measured similarly across the countries, we followed Paternoster et al. (1998) and conducted $\mathrm{Z}$ tests of statistical significance to gauge whether there were country-specific effects. When the variables were not comparably measured across countries, these tests would be inappropriate. Additionally, we tested for differences within country by the child's gender, age, and, in the U.S. only, by race. Finally, we evaluate whether the effects of maternal age and race are notably contributing to the findings.

\subsection{RESULTS}

\subsection{COMPARING PREDICTORS OF VERBAL FACILITY BY COUNTRY}

Our results in Table 4, Model 1 show several commonalities as well as some differences in children's verbal facility across the two countries. In general, we find that low birth weight children and those with physical health problems have lower verbal facility in both countries. We also see that when mothers have higher test scores on the AFQT in the U.S. and reading and math tests in G.B., children have higher PPVT-R test scores. The mother's family of origin also matters. We find lower verbal facility among children whose grandfathers worked in some non-professional occupations in each society (results not shown).

We did, however, find several differences across the two societies. First, older children in the U.S. have better verbal facility than younger children, while age has no 
effect in Britain. Second, nonwhite children in the U.S. have lower verbal facility (relative to white children) and U.S. children whose grandparents are more highly educated have higher verbal facility. These effects are not present in G.B. Third, the mother's educational track and her aspirations matter in G.B., while those effects are absent in the U.S. In Britain, children whose mothers attended a lower educational track have lower verbal facility than children whose mothers attended a higher track, and children whose mothers had higher educational aspirations when growing up have children with better verbal facility.

In Model 2 we assess parental work effects by incorporating parental occupation, work hours, and wages, as well as the father's educational attainment; the coefficients for grandparents' and parental occupations are not shown. Most of the effects found in Model 1 remain significant in Model 2. Even after controlling for maternal and paternal work effects, children's verbal facility remains strongly affected by low birth weight, physical health problems, and maternal intellectual ability. Mother's educational aspirations is no longer significant in Britain. However, we find more evidence of the significance of educational in Britain as children have higher verbal facility if their mother attended a grammar school relative to a comprehensive school. Results from Model 2 are consistent with work effects perspectives in both societies, although in different ways. In Britain, we find that verbal facility is lower when fathers are not employed. In the U.S., children have lower PPVT-R scores when fathers work overtime hours. Mother's work hours and wages are not associated with verbal facility in either country. Across both countries, Model 2 reveals the importance of father's education for children's verbal facility, as well as father's wages in the U. S. In both societies, higher verbal scores are found when fathers 
have more schooling. Overall, these results highlight the importance of father's educational attainment and parental employment for child verbal facility.

In Model 3, we add variables related to family social capital including family structure, family size and the quality of children's home environments. In G.B. family structure has no impact on verbal facility, but in the U.S., children living in single-mother families have lower verbal test scores (relative to children whose mothers are married). In both countries family size and home environment have strong effects. Children from larger families have lower verbal facility while children growing up in stronger home environments have greater verbal facility than those in weaker environments. All of the effects from previous models remain significant in Britain, with the exception of mother's math test score. Additionally, we show for the first time that the sex of the child has an effect on verbal facility in G.B., with boys scoring higher than girls. In the U.S., there are more changes in the final model. Once we include measures for family structure, size and home environment, many of the work effects from Model 2 are no longer significant in the U.S. Overall, the final model demonstrates the negative effect of larger family sizes on children's verbal scores, as well as the importance of strong home environments in developing child verbal facility.

\subsection{COMPARING PREDICTORS OF CHILD READING ACHIEVEMENT BY COUNTRY}

Table 5, Model 1 shows similarities in predicting children's reading achievement (PIAT reading recognition) by country, with health limitations and male gender being negative predictors in both societies; grandparents' occupation is controlled but not shown. In the U.S., older children and those with low birthweight have lower reading scores, but these factors have no effect on reading achievement in G.B. Greater maternal 
cognitive abilities result in higher reading achievement among children in both countries, as do educational aspirations in G.B.

Most of these effects are maintained in Model 2, with maternal education beneficial in both societies. As in the PPVT-R models discussed earlier, we find support for work socialization perspectives. Fathers' work hours are also consequential in both countries. Having a father who works overtime hours (in the U.S.) or who only works part-time hours (in G.B.) is detrimental to reading scores. Fathers' wages are related to higher reading achievement among children in the U.S. These findings appear even with controls for parental occupation (not shown).

We include family social capital variables in Model 3 and find, in both countries, that larger family sizes are detrimental to children's reading achievement while stronger home environments lead to greater reading achievement. We find no evidence that parental marital status influences reading scores in either country. Many of these effects continue even when we include a rigorous control, PPVT-R, in Model 4.

\subsection{COMPARING PRECTORS OF CHILD MATHEMATICS ACHIEVEMENT BY}

\section{COUNTRY}

Examining the models predicting math achievement in Table 6 shows many similarities to the PIAT reading achievement; again, grandparents' occupations are controlled but not shown. As with our reading achievement results, children in both countries who have health limitations that prevent them from studying with peers tend to have lower PIAT math scores. In G.B., older children and those with low birthweight, and those whose mothers are racial-ethnic minorities in both countries have lower math achievement. Maternal education influences child math achievement in the U.S. as child math scores are lower among mothers who were "tracked" into the general track rather 
than college preparatory track in the U.S. Mother's cognitive ability is helpful in both countries. In Model 2 we find that while the effect of educational tracking among U.S. mothers is no longer significant, father's education is helpful for child math achievement in the U.S. All other effects from model 1 remain and we see low birthweight effects in Great Britain. As in the prior two tables, this models controls for parental occupations but coefficients are not shown.

In Model 3, we incorporate family social capital to better understand math achievement. Mother's marital status had no effect on math achievement in Great Britain but children in single-mother households in the U. S. are disadvantaged; however, home environment is strongly related to higher math scores in both countries. In the U.S. family size has a negative effect on math achievement with children who grow up among more siblings having lower math ability. We also find that among U.S. mothers, low part-time work hours is positively related to math achievement. All other effects remain similar, although in some cases are weaker, with the exception of low birthweight in G.B, which is no longer significant. Controlling for PPVT-R reduces the HOME effect in G.B. to non-significance, as well as the single-household effect in the U.S.

\subsection{TESTS FOR DIFFERENCES BY COUNTRY}

When an effect was significant in one country or in both and when variables were measured in a similar way, we tested for significant differences between regression coefficients using Z tests (Paternoster, Brame, Mazerolle and Piquero 1998). We found that for PPVT-R, the effects of child's age $(Z=2.88)$ and single mother status $(Z=4.10)$ were statistically significant, while for PIAT-R, only child's age was significant $(\mathrm{Z}=$ -3.56). There were no statistically significant differences across the countries for PIATMath. These findings suggest effects are largely similar by country. 


\subsection{INTERACTIONS BY STATUS CHARACTERISTICS}

It is possible that the processes we have studied vary for different subgroups within each country. We used Chow tests to evaluate whether the independent variables have different effects on boys versus girls, younger children versus older children, and whites versus nonwhites (in U.S. only). None of these tests was statistically significant. Thus, we conclude that the models are robust within each country by age and gender, and, for the U.S., by race.

\subsection{ADDITIONAL ANALYSES}

We considered whether our findings are driven by the very different proportions of racial minorities in the U.S. versus the British samples. We re-estimated Model 3 for Tables 4, 5 and 6 after eliminating racial minorities from both the U.S. sample $(\mathrm{N}=1,555)$ and the G.B. sample $(\mathrm{N}=1,290)$. Using the same $\mathrm{Z}$ tests as noted above to assess whether there are differences in regression coefficients across countries for variables measured in a similar way, we find the effect of mother's employment status is statistically significant for PIAT-Math $(Z=-2.04)$ and PPVT-R $(Z=-1.72)$. There were no significant differences between the U.S. and G.B. for PIAT-Reading.

\subsection{DISCUSSION}

Our findings suggest that characteristics of children, their parents and their families are important in both G.B. and the U.S. in influencing child verbal facility. Low birthweight, child health limitations, maternal cognition, family size and children's home environments stand out as important commonalities. In addition, our final models predicting reading and mathematics achievement show strong effects of PPVT-R. These findings highlight that some of these background factors work indirectly through PPVT$\mathrm{R}$, even when direct effects weaken or disappear. 
At the same time, one difference for PPVT-R stands out as particularly relevant to our concerns regarding differing welfare state effects: children in single-mother households in the U.S. are disadvantaged in PPVT-R while children in G.B. are not. Such a difference suggests that it may be some aspect of British welfare state support that is better supporting single mothers in G.B. relative to their U.S. counterparts. Recall, also, that this difference appears in the presence of stringent controls for a variety of other demonstrated predictors. Overall, however, the number of similarities in the models far outstrips differences, suggestive though this single-mother difference may be.

Some of these findings are replicated when we turn to analysis of reading achievement. Health limitations and male gender are negatively associated with reading achievement, while maternal cognition is helpful in both societies. Again we find that family size and stronger home environments are similar in their negative and positive effects, respectively, in both societies. Taken together, these findings show strong similarity to those discussed regarding verbal facility. The differences in single-mother household effects are not present, however, thus limiting our inferences regarding the single-mother effects so far to verbal facility.

Finally, we consider our models predicting mathematics achievement in both societies. There remain a few similarities in effects cross-culturally. Health limitations are negatively associated with math achievement, while higher levels of maternal cognition are helpful, as are children's home environments. Importantly, however, family size has a negative effect on math achievement in the U.S. but not in Great Britain. These findings suggest that the stronger welfare state in G.B. may be compensating for larger family sizes in G.B., while family size effects in the U. S. remain significant in the third model. Again, it is possible that welfare state supports in G.B. are consequential in 
these findings. Overall, however, we continue to find considerable similarity in effects across the two models, these final differences notwithstanding.

\subsection{CAN THE WELFARE STATE REPLACE PARENTS?}

These findings provide, at best, mixed support for Esping-Anderson's thesis that a developed welfare state can substitute for parental investment in children. For example, the more developed welfare state in G.B. does not appear to compensate for the role that family social capital plays in the processes through which children develop verbal and mathematical skills. We have found that children's home environments are equally important in both societies. These findings indicate that the efforts parents make to construct cognitively stimulating, safe and affectively warm environments affect child cognition, even in the presence of stringent controls, and that these efforts pay positive dividends in both societies. The positive effects of maternal cognition also support this conclusion.

Our findings also show that the more developed welfare state in G. B. is not a panacea. Child ill health is associated with lower levels of cognition in both societies. Thus, helpful though the state system of health care in G. B. undoubtedly is, this aspect of the welfare state does not insulate British children's cognition from the negative impact of their ill health. We also see resource diffusion effects in both societies such that child verbal facility and verbal achievement suffer in families with greater numbers of children. Taken together, and combining these findings with those noted above, we have substantial support for the notion that characteristics of parents, families and of children themselves are very consequential in both societies in promoting child cognition.

We have noted that children's verbal facility in single-mother families G. B. may be more insulated than comparable children in the U. S. This encourages us to consider 
whether the more developed welfare state in G.B. allows single mothers to enhance their investment in children in ways we cannot detect in this analysis. Perhaps some aspect of the welfare system in G. B. allows single mothers to shift resources to support verbal facility of their children. In addition, larger family sizes are more detrimental to mathematics achievement in the U.S than in G.B., again suggesting possible resource shifting in G.B.

These findings provide additional insight into the micro-level underpinnings of attainment processes involving the effects of family characteristics on child cognition, a critical precursor of educational attainment, which, in turn is strongly linked to placement in stratification systems in both the U.S. and G.B. They underscore the importance of families in promoting social mobility in both societies, while also identifying two aspects of family structure in G. B. that, when weaker, may be bolstered by welfare state support. We recognize, however, that these conclusions are based on analyses of data from the early 1990s.

\subsection{WHAT ABOUT TODAY?}

A relevant question is how might our findings differ if we were able to replicate our study with data from 2012 or later, after the Great Recession. For the U.S. there have been long term efforts to at least partly "catch up" with liberal welfare state provisions that are common in Europe. Passage and implementation of the Affordable Care Act is one way in which the U.S. is moving towards a model of greater state support for citizen and family health care. At the same time, the strong ethic of individual responsibility present in the U.S. likely accounts for slow progress towards greater support for U.S. families. 
However, we are also alert to the recent changing nature of family supports within G.B. The recent world-wide recession has played a significant role in G.B.'s decision to reduce supports to British families (Thomas 2010). These changes suggest that the welfare state in G.B., although more developed than in the U.S. in 1994, may, in the future, look more like that in the U.S. Such developments might force British parents to realign their resources in ways that affect child cognition. Thus, future research might find that children in single-mother families or larger families in G. B. might be more challenged in their cognitive achievement. Whether our similar findings across societies in terms of the effects of children's home environment or child ill health would continue is unclear.

\subsection{LIMITATIONS AND DIRECTIONS FOR FUTURE RESEARCH}

We note important limitations to our analyses. We do not have actual measures of welfare state strength, which would be more useful in comparing processes across more than two societies. Nor can we measure the extent to which families are taking advantage of various state programs or which aspects of the respective welfare states might account for the differences we do find; again, such work is beyond the scope of our analysis. In addition, it is possible that Esping-Andersen's thesis would have received stronger support had we been able to contrast children in the U.S. with children in an even stronger welfare state than in G.B, such as that in Norway. Unfortunately, the micro-level Norwegian data needed for such a comparison are not available. Recall that we require longitudinal data, the same/similar measures across societies, and large numbers of cases.

What we have been able to do is make inferences regarding how the respective welfare states may be operating differently for families in G.B. and the U.S. (see also Olafsdottir 2007). We have suggested that, to a large extent, the British welfare state is 
not substituting for parental inputs in promoting child cognition. We reached this same conclusion in analyses of children's home environments (Campbell and Parcel 2010) and for children's behavior problems (Parcel, Campbell and Zhong 2012). In the case of cognition, however, we did identify two findings that are suggestive of the salutary effects of the welfare state in G.B. compared to the U.S., specifically for the critical cases of single-mother families and larger families, at least as of the early 1990s. Overall, however, it does not appear that the more developed welfare state in G.B. is substituting for parental resources, although it may soften the deleterious effects of selected family inputs when they are relatively scarce or stretched thin. In addition, we recommend that others seek additional opportunities to estimate micro-level models that compare other social processes across societies. Although the empirical requirements of these investigations are demanding, our understanding of the similarities and differences between social processes across cultures requires this investment. 


\section{NOTES}

1. Larger family sizes can also dilute availability of parental financial and human capital with analogous consequences for children (Downey 1995).

2. We would expect that in a society that is strongly class based, parents will have greater capacity to pass along their social class advantages to their children, either through inheritance of wealth, or by facilitating children's educational attainment. Alternatively, such findings might reflect different patterns of investment in children in G.B. compared to the U.S., perhaps via a family allowance that allows parents to strengthen investment at home.

3. These children would likely introduce interaction effects of parental age on investment in ways that would take us well beyond the scope of this analysis. In addition, particularly in the NCDS, the numbers of children older than 13 born to these British parents is very small $(\mathrm{N}=199)$. If this $\mathrm{N}$ were further restricted to the children of the British mothers, reliable estimates would be at risk.

4. The dummy categories tapping educational track are consistent within societies, but more difficult to compare cross-culturally. In the U.S., students who were on the college preparatory track and the general track are typically found within the same school buildings, while those taking vocational courses are often be housed elsewhere. In G.B., the traditional system had placed students following different tracks literally into different schools. When the British system changed gradually during the $20^{\text {th }}$ century to favor comprehensive schools, these replaced the secondary modern and elite grammar schools with students following separate tracks within the same buildings. The omitted categories of College Prep in the U.S. and Comprehensive track in G.B. are thus not strictly 
comparable because the U.S. children were on separate tracks, while in G.B. they were in different schools.

5. Missing data was more frequent in the NLSY than in the NCDS, although proportionally similar. For the NCDS, there was low missing data for child health $(\mathrm{N}=6)$ and for spouse's work hours $(\mathrm{N}=4)$; somewhat higher missing data for maternal cognition $(\mathrm{N}=65)$ and grandparent's occupation $(\mathrm{N}=58)$ and highest missing data for educational aspirations $(\mathrm{N}=134)$, maternal work hours $(\mathrm{N}=102)$ and spouse's pay $(\mathrm{N}=291)$. For the NLSY, missing data was low for child health problems $(\mathrm{N}=3)$, higher for maternal AFQT $(\mathrm{N}=140)$ and maternal educational expectations $(\mathrm{N}=103)$, and highest for grandfather's occupation $(\mathrm{N}=1,006)$ and maternal occupation $(\mathrm{N}=75)$.

6. To simplify our presentation and focus more clearly on family characteristics and effects, we have excluded coefficients associated with grandparents' and parental occupations from Tables 4, 5, and 6, although these variables are still controlled in the models. For all three dependent variables, inclusion of children's home environments, family size and marital status effects weakened parental occupational effects, thus suggesting that parental occupation works through these aspects of family social capital and family structure. 


\section{References}

Allison, P. D. 2002. Missing Data. Thousand Oaks, CA: Sage.

Amato, P. R. 2010. "Research on Divorce: Continuing Trends and New

Developments." Journal of Marriage and Family 72(3): 650-666.

Baker, P. C., C. K. Keck, F. L. Mott, and S. V. Quinlan. 1993. NLSY Child Handbook, Revised Edition: A Guide to the 1986-1990 National Longitudinal Survey of Youth Child

Data. Columbus, OH: The Center for Human Resource Research, The Ohio State University.

Blau, F. D. and L. M. Kahn. 2013. "Female Labor Supply: Why Is the United States Falling Behind?" American Economic Review 103 (3): 251-256.

Breen, R., and J. O. Jonsson. 2005. "Inequality of Opportunity in Comparative Perspective: Recent Research on Educational Attainment and Social Mobility.” Annual Review of Sociology 31: 223-243.

Brown, S. 2004. "Family Structure and Child Well-Being: The Significance of Parental Cohabitation." Journal of Marriage and Family 66: 351-367.

Campbell, L. A. and T. L. Parcel. 2010. “Children's Home Environments in Great Britain and the United States." Journal of Family Issues 31: 559-584.

Coleman, J. 1990. Foundations of Social Theory. Cambridge, MA: Belknap Press. 
Coltrane, S. 1996. Family Man: Fatherhood, Housework and Gender Equity. New York: Oxford.

Conger, R. D., K. J Conger, and M. J. Martin. 2010. "Socioeconomic Status, Family Processes, and Individual Development." Journal of Marriage and Family 72(3): 685-704.

Craig, L. and K. Ullan. 2011. "How Mothers and Fathers Share Childcare: A CrossNational Time-Use Comparison.” American Sociological Review 76: 834-861.

Crouse, J., P. Mueser, C. Jencks, and C. S. Reichardt. 1979. "Latent Variable Models of Status Attainment." Social Science Research 8(4): 348-368.

Davis-Kean, P. E. 2005. "The Influence of Parent Education and Family Income on Child Achievement: The Indirect Role of Parental Expectations and the Home Environment." Journal of Family Psychology 19: 294-304.

Downey, D. B. 1995. "When Bigger Is Not Better: Family Size, Parental Resources and Children's Educational Performance." American Sociological Review 60: 746-761.

Dufur, M. J., T. L. Parcel and K. P. Troutman. 2013. “Does Capital at Home Matter More than Capital at School? Social Capital Effects on Academic Achievement." Research in Social Stratification and Mobility 31: 1-21.

Dufur, M. J., T. L. Parcel, and B. A. McKune. 2008. "Capital and Context: Using Social Capital at Home and at School to Predict Child Social Adjustment." Journal of Health and Social Behavior 49(2): 146-161. 
Duncan, Gg. J., J. Brooks-Gunn, and P. K. Klebanov. 1994. "Economic Deprivation and Early Childhood Development." Child Development 65: 296-318.

Dunn, L., and L. Dunn. 1981. PPVT-R Manual. Circle Pines, MN: American Guidance Service.

Esping-Anderson, G. 2002. Why We Need a New Welfare State. New York: Oxford.

Ferber, M., B. O'Farrell, and L. Allen. 1991. Work and Family: Policies for a Changing Workforce. Washington, DC: National Academy Press.

Fogelman, K., (Ed.) 1983. Growing Up in Great Britain: Collected Papers from the National Child Development Study. Basingstoke, UK: Macmillan.

Fox, J. 1991. Regression Diagnostics: An Introduction. Thousand Oaks, CA: Sage.

Gornick, J. and J. Jacobs. 1998. "Gender, the Welfare State, and Public Employment: A Comparative Study of Seven Industrialized Countries." American Sociological Review 63:688-710.

Gregg, P., M. Gutierrez-Domenech and J. Waldfogel. 2003. The Employment of Married Mothers in Great Britain: 1974-2000.” http://www.bristol.ac.uk/media-library/sites/ cmpo/migrated/documents/wp78.pdf.

Guo, G. 1998. "The Timing of the Influences of Cumulative Poverty on Children's Cognitive Ability and Achievement." Social Forces 77(1): 257-287.

Hakim, C. 2000. Work-lifestyle Choices in the 21st Century: Preference Theory. New York: Oxford. 
Heckman, J. 2008. "Schools, Skills, and Synapses." Economic Inquiry 46:289-324.

Hsin, A. and C. Felfe. 2014. "When Does Time Matter? Maternal Employment, Children's Time With Parents, and Child Development.” Demography 51:1867-1894.

Jencks, C. 1979. Who gets ahead?: The Determinants of Economic Success in America. New York: Basic Books.

Jesson, D. 2000. "The Comparative Evaluation of GCSE Value-Added Performance by Type of School and LEA." University of York Discussion Paper in Economics, No. 2000/52, York, UK.

Joshi, H. E., E. C. Cooksey, R. D. Wiggins, A. McCulloch, G. Verropoulou, and L.

Clarke. 1999. "Diverse Family Living Situations and Child Development: A Multilevel Analysis Comparing Longitudinal Evidence from Britain and the U. S." International Journal of Law, Policy and the Family 13:292-314.

Kammerman, S. B. and A.J. Khan (Eds). 1997. Family Change and Family Policies in Great Britain, Canada, New Zealand and the United States. New York: Oxford.

Kerckhoff, A. 1990. Getting Started: Transition to Adulthood in Great Britain. Boulder, CO: Westview Press.

Kerckhoff, A. 1993. Diverging Pathways: Social Structure and Deflections. New York: Cambridge. 
Kikuzawa, S. 2006. "Multiple Roles and Mental Health in Cross-Cultural Perspective:

The Elderly in the United States and Japan." Journal of Health and Social

Behavior, 47(1), 62-76.

Kim, H. S. 2011. “Consequences of Parental Divorce for Child Development.” American Sociological Review, 76(3), 487-511.

Kohn, M. L. and C. Schooler. 1983. Work and Personality: An Inquiry into the Impact of Social Stratification. Norwood, NJ: Ablex.

Kohn, M. L. and K. M. Slomczynski. 1990. Social Structure and Self Direction: A Comparative Analysis in the United States and Poland. Cambridge, MA: Basil Blackwell.

Lareau, A. 2011. Unequal Childhoods: Class, Race, and Family life. Berkeley: University of California Press.

Little, R. J. A. and D. B. Rubin. 2002. Statistical Analysis with Missing Data. New York: John Wiley and Sons.

Marsiglio, W. and K. Roy. 2012. Nurturing Dads: Fatherhood Initiatives beyond the Wallet. New York: Russell Sage Foundation.

Mayer, S. E. 1997. What Money Can't Buy: Family Income and Children's Life Chances. Cambridge: Harvard. 
McCulloch, A., R. D. Wiggins, H. E. Joshi, and D. Sachdev. 2000. "Internalising and

Externalising Children's Behavior Problems in Britain and the US: Relationships to Family Resources." Children and Society 14:368-83.

McDonough, P., D. Worts, and A. Sacker. 2010. "Socioeconomic Inequalities in Health Dynamics: A Comparison of Britain and the United States." Social Science \& Medicine, 70 (2), 251-260.

McLanahan, S. and C. Percheski. 2008. "Family Structure and the Reproduction of Inequalities.” Annual Review of Sociology 34: 257-276.

McLeod, J. D. and K. Kaiser. 2004. "Childhood Emotional and Behavioral Problems and Educational Attainment." American Sociological Review 69:636-58.

Michael, R. 2003. "Children's Cognitive Development in Britain and the U. S.” International Journal of Behavioral Development 7: 396-408.

Mirowsky, J. and C. E. Ross. 2003. Education, Social Status, and Health. New York: Aldine de Gruyter.

NCDS. 1998. National Child Development Survey Child and Parent Data, Rounds 1-5, Users ' Guide. Columbus, OH: Center for Human Resource Research, The Ohio State University. NLS. 1999.

NLS Handbook 1999: The National Longitudinal Surveys. Columbus, OH: Center for Human Resource Research, The Ohio State University. 
O'Connor, J. S., A. S. Orloff, and S. Shaver. 1999. States, Markets, Families: Gender,

Liberalism and Social Policy in Australia, Canada, Great Britain and the United States.

Cambridge: Cambridge University Press.

Olafsdottir, S. 2007. "Fundamental Causes of Health Disparities: Stratification, the Welfare State, and Health in the United States and Iceland." Journal of Health and Social Behavior 48:239-53.

Parcel, T. L., L. A. Campbell and W. Zhong. 2012. “Children’s Behavior Problems in Great Britain and the United States." Journal of Health and Social Behavior 53: 165-182.

Parcel, T. L.., and M. J. Dufur. 2001. "Capital at Home and at School: Effects on Student Achievement.” Social Forces, 79(3), 881-911.

Parcel, T. L. and E. G. Menaghan. 1994a. "Early Parental Work, Family Social Capital, and Early Childhood Outcomes." American Journal of Sociology 99:972-1009.

Parcel, T. L. and E. G. Menaghan. 1994b. Parents' Jobs and Children's Lives. New York: Aldine.

Paternoster, R., R. Brame, P. Mazerolle, and A. Piquero. 1998. "Using the Correct Statistical Test for the Equality of Regression Coefficients." Criminology 36:859-66.

Powell, M.A. 1999. "Family and Schooling Effects on Educational Attainment: Great Britain and the United States Compared." PhD dissertation, Department of Sociology, The Ohio State University, Columbus, $\mathrm{OH}$. 
Sayer, L. and J. Gornick. 2012. "Cross-national Variation in the Influence of Employment Hours on Child Care Time.” European Sociological Review 28: 421-442.

Schaub, M. 2010. "Parenting for Cognitive Development from 1950 to 2000 the Institutionalization of Mass Education and the Social Construction of Parenting in the United States." Sociology of Education, 83(1), 46-66.

Sewell, W. H. and R. M. Hauser. 1975. Education, Occupation, and Earnings. Achievement in the Early Career. New York: Academic Press.

Thomas, L. 2010. "In Sharp Change, Britain Will Reduce Child Benefits for the Middle Class." New York Times, October 5.

Treas, J. and S. Drobnic. 2010. Dividing the Domestic Men, Women \& Household Work in Cross-National Perspective. Stanford, CA: Stanford.

Warren, J. R. and R. M. Hauser. 1997. "Social Stratification across Three Generations: New Evidence from the Wisconsin Longitudinal Study." American Sociological Review 62:561-72. 
Table 1. Summary of Hypothesized Effects of Key Predictors on Cognition

\begin{tabular}{|c|c|c|c|c|}
\hline Conceptual predictors & $\begin{array}{l}\text { Expected } \\
\text { direction }\end{array}$ & $\begin{array}{c}\text { Capital } \\
\text { equally } \\
\text { influential }\end{array}$ & $\begin{array}{l}\text { Families more } \\
\text { important in } \\
\text { G.B. than } \\
\text { U.S. }\end{array}$ & $\begin{array}{l}\text { Families less } \\
\text { important in } \\
\text { G.B. than } \\
\text { U.S. }\end{array}$ \\
\hline
\end{tabular}

\section{Child Characteristics}

Health problems

Low birthweight

Sex (male)

Age

\section{Maternal Characteristics}

Minority race/ethnicity

Age

Education attainment

Academic school track

Cognitive skills

Investment in own learning

\section{Paternal Characteristics}

Age

Education attainment

\section{Family of Origin}

Intact family structure

Grandparent's education

Grandparent's occupation

Mother's educational

expectations

\section{Maternal and Paternal}

Work Characteristics

Wages
Full-time work hours
Professional occupational
status

\section{Family Structure}

Intact family status

Family size

Home Environment

$\begin{array}{lll}= & > & < \\ = & > & < \\ = & > & < \\ = & > & <\end{array}$

- $=$

$<$

$<$

$<$

$<$

$<$

$<$

$+\quad>\quad<$

$+\quad=$

$<$

$+\quad=\quad>\quad<$

$+\quad=$

$+\quad=$

$+\quad=$

$=$

$>$

$<$

$<$

$<$

$<$

$+$

$=$

$+\quad=$

$>$

$<$

$<$

$+\quad=$

$<$$$
<
$$$$
<
$$$$
<
$$

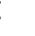

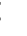$$
<
$$

$<$

$<+<$

$<$


Child Cognition in the U.S. and Great Britain

$\begin{array}{lllll}\text { PPVT-R } & + & \text { NA } & \text { NA }\end{array}$

a $+=$ positive; $-=$ negative

Table 2: Concepts with Measures from the NLSY79 and NCDS 


\section{Concept}

Measures

NLSY79

Measures

NCDS

\section{DEPENDENT VARIABLES}

Peabody Individual Achievement Test - Math

Peabody Individual Achievement Test - Reading

Peabody Picture Vocabulary Test - Revised

1994.

Test measuring children's math achievement,

Test measuring children's reading achievement, 1994.

Test measuring children's hearing vocabulary, 1994.

1991.

Same as NLSY,

Same as NLSY, 1991.

Same as NLSY, 1991.

\section{INDEPENDENT VARIABLES}

\section{Child Characteristics}

Health problems

affect

Mother's report of child's health problems that

ability to attend school, play sports or play with other

children, 1994. Health problems $=1$. 
Table 3. Means and Standard Deviations

\begin{tabular}{|c|c|c|c|c|c|}
\hline \multirow[b]{3}{*}{ Variables } & \multirow{2}{*}{\multicolumn{2}{|c|}{$\begin{array}{c}\text { NLSY } \\
\mathbf{N}=\mathbf{3 , 4 3 8 ^ { a }}\end{array}$}} & \multicolumn{3}{|c|}{ NCDS } \\
\hline & & & \multicolumn{3}{|c|}{$\mathrm{N}=1,429^{\mathrm{a}}$} \\
\hline & $\begin{array}{r}\text { Me } \\
\text { an }\end{array}$ & $\begin{array}{r}\text { Std } \\
\text { Dev } \\
\text {. }\end{array}$ & $\begin{array}{r}\mathbf{M} \\
\mathbf{e a} \\
\mathbf{n}\end{array}$ & $\begin{array}{r}\text { Std } \\
. \text { De } \\
\text { v. }\end{array}$ & \\
\hline PIAT Math & $\begin{array}{l}99 . \\
46\end{array}$ & $\begin{array}{l}13 . \\
32\end{array}$ & $\begin{array}{l}10 \\
6 . \\
78\end{array}$ & $\begin{array}{l}13 . \\
05\end{array}$ & * \\
\hline PIAT Reading & $\begin{array}{l}102 \\
.58\end{array}$ & $\begin{array}{l}14 . \\
61\end{array}$ & $\begin{array}{l}10 \\
9 . \\
29\end{array}$ & $\begin{array}{l}15 . \\
28\end{array}$ & * \\
\hline PPVT-R & $\begin{array}{l}90 . \\
21\end{array}$ & $\begin{array}{l}18 . \\
67\end{array}$ & $\begin{array}{l}98 \\
.6 \\
8\end{array}$ & $\begin{array}{l}15 . \\
46\end{array}$ & * \\
\hline \multicolumn{6}{|l|}{$\begin{array}{l}\text { Child } \\
\text { characteristics }\end{array}$} \\
\hline $\begin{array}{l}\text { Health } \\
\text { problems }\end{array}$ & $\begin{array}{l}0.0 \\
5\end{array}$ & & $\begin{array}{l}0 . \\
09\end{array}$ & & * \\
\hline $\begin{array}{l}\text { Low } \\
\text { birthweight }\end{array}$ & $\begin{array}{l}0.0 \\
7\end{array}$ & & $\begin{array}{l}0 . \\
04\end{array}$ & & * \\
\hline Sex (male) & $\begin{array}{l}0.5 \\
0\end{array}$ & & $\begin{array}{l}0 . \\
50\end{array}$ & & \\
\hline Age & $\begin{array}{l}9.4 \\
7\end{array}$ & $\begin{array}{l}2.5 \\
0\end{array}$ & $\begin{array}{l}8 . \\
37\end{array}$ & $\begin{array}{l}2.4 \\
8\end{array}$ & * \\
\hline \multicolumn{6}{|l|}{$\begin{array}{l}\text { Maternal } \\
\text { Characteristics }\end{array}$} \\
\hline $\begin{array}{c}\text { Minority } \\
\text { race/ethnicity }\end{array}$ & $\begin{array}{l}0.5 \\
5\end{array}$ & & $\begin{array}{l}0 . \\
02\end{array}$ & & * \\
\hline Age (US) & $\begin{array}{l}32 . \\
99\end{array}$ & $\begin{array}{l}2.3 \\
0\end{array}$ & --- & --- & \\
\hline $\begin{array}{c}\text { Education } \\
\text { attainment (US) }\end{array}$ & $\begin{array}{l}12 . \\
36\end{array}$ & $\begin{array}{l}3.0 \\
1\end{array}$ & & & \\
\hline $\begin{array}{c}\text { Education } \\
\text { attainment }(\mathrm{GB})\end{array}$ & & & $\begin{array}{l}4 . \\
79\end{array}$ & $\begin{array}{l}4.9 \\
2\end{array}$ & \\
\hline \multicolumn{5}{|l|}{$\begin{array}{l}\text { Academic } \\
\text { school track }\end{array}$} & \\
\hline $\begin{array}{l}\text { College } \\
\operatorname{prep}^{\mathrm{b}}(\mathrm{US})\end{array}$ & $\begin{array}{l}0.2 \\
7\end{array}$ & & -- & --- & \\
\hline $\begin{array}{l}\text { General } \\
\text { track (US) }\end{array}$ & $\begin{array}{l}0.5 \\
7\end{array}$ & & --- & --- & \\
\hline
\end{tabular}




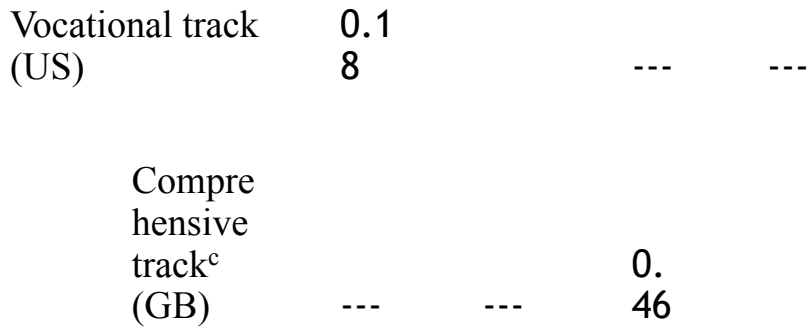

Grammar school

0.

(GB)

-- $\quad---\quad 09$

Seconda
ry
modern
school

school track

Other

(GB)

0.

Private 02

$\begin{array}{llll}\text { school }(\mathrm{GB}) & -- & -.- & 03\end{array}$



Skills

Cognitive

AFQT81 score

(US)

$3.4 \quad 2.7$

81

Reading test

(GB)

$\begin{array}{lll} & & 22 \\ & & \\ \ldots & .4 & 7.4\end{array}$

\begin{tabular}{|c|c|c|c|c|}
\hline $\begin{array}{l}\text { Math } \\
\text { test (GB) }\end{array}$ & --- & --. & $\begin{array}{l}11 \\
.9 \\
9\end{array}$ & $\begin{array}{l}7.3 \\
1\end{array}$ \\
\hline $\begin{array}{c}\text { Investment } \\
\text { in own learning }\end{array}$ & $\begin{array}{l}1.4 \\
4\end{array}$ & $\begin{array}{l}0.7 \\
0\end{array}$ & $\begin{array}{l}2 . \\
17\end{array}$ & $\begin{array}{l}0.7 \\
3\end{array}$ \\
\hline
\end{tabular}

Paternal

Characteristics

$\begin{array}{ccccc} & & 3 & \\ & & 5 . & 4 . \\ & & & 5 & 0 \\ \text { Age } & 35.80 & 4.12 & 1 & 5\end{array}$




\begin{tabular}{|c|c|c|c|c|}
\hline $\begin{array}{l}\text { Education } \\
\text { attainment }\end{array}$ & 12.64 & & 2.21 & \\
\hline $\begin{array}{l}\text { Family of } \\
\text { Origin }\end{array}$ & & & & \\
\hline $\begin{array}{l}\text { Intact family } \\
\text { structure }\end{array}$ & $\begin{array}{l}0.6 \\
5\end{array}$ & & $\begin{array}{l}0 . \\
88\end{array}$ & \\
\hline $\begin{array}{l}\text { Grandparent's } \\
\text { education }\end{array}$ & $\begin{array}{l}10 . \\
88\end{array}$ & $\begin{array}{l}3.4 \\
2\end{array}$ & $\begin{array}{l}14 \\
.7 \\
8\end{array}$ & $\begin{array}{l}1.7 \\
3\end{array}$ \\
\hline
\end{tabular}

Grandparent's

occupation

Professional $^{\mathrm{d}}$

0.2

0.

$0 \quad 03$

professional

$\begin{array}{llll}\text { (GB) } & - & - & \\ & & & \end{array}$




Child Cognition in the U.S. and Great Britain

(US)

$\begin{array}{ll}\text { Farm } & 0.0 \\ & 8\end{array}$

Mother's

educational

expectations

$\begin{array}{llll}0.3 & 0.4 & 1 . & 0.7 \\ 5 & 8 & 65 & 2\end{array}$

Maternal work characteristics

\begin{tabular}{|c|c|}
\hline $\begin{array}{l}\text { Employment } \\
\text { tatus }(1=\text { yes })\end{array}$ & $\begin{array}{l}0.6 \\
3\end{array}$ \\
\hline Wages & $\begin{array}{l}9.2 \\
9\end{array}$ \\
\hline
\end{tabular}

Work hours

\begin{tabular}{|c|c|}
\hline Overtime & $\begin{array}{l}0.0 \\
9\end{array}$ \\
\hline time $^{\mathrm{d}} \quad$ Full & $\begin{array}{l}0.7 \\
4\end{array}$ \\
\hline $\begin{array}{l}\text { Moderate part- } \\
\text { time }\end{array}$ & $\begin{array}{l}0.1 \\
2\end{array}$ \\
\hline part-time $^{\text {Low }}$ & $\begin{array}{l}0.0 \\
6\end{array}$ \\
\hline
\end{tabular}

Occupation

\begin{tabular}{|c|c|c|c|}
\hline $\begin{array}{l}\text { Professi } \\
\text { onal, }{ }^{\mathrm{d}} \\
\text { manager } \\
\text { ial, } \\
\text { technica } \\
1 \text { (and } \\
\text { also } \\
\text { military } \\
\text { in US) }\end{array}$ & $\begin{array}{l}0.1 \\
9\end{array}$ & $\begin{array}{l}0 . \\
21\end{array}$ & \\
\hline Clerical & $\begin{array}{l}0.2 \\
3\end{array}$ & --- & --- \\
\hline $\begin{array}{l}\text { Service } \\
\text { and sales (US) }\end{array}$ & $\begin{array}{l}0.0 \\
2\end{array}$ & -- & -- \\
\hline $\begin{array}{l}\text { Craft, } \\
\text { operator } \\
\text {, laborer } \\
\text { and } \\
\text { farming } \\
\text { (US) }\end{array}$ & $\begin{array}{l}0.3 \\
6\end{array}$ & -- & -- \\
\hline $\begin{array}{l}\text { Skilled } \\
\text { non-manual } \\
\text { (GB) }\end{array}$ & -- & $\begin{array}{l}0 . \\
40\end{array}$ & \\
\hline
\end{tabular}


Child Cognition in the U.S. and Great Britain

$\begin{array}{rlll}\text { Skilled } & & & 0 . \\ \text { manual (GB) } & --- & -- & 07 \\ \text { Partly } & & & 0 . \\ \text { skilled (GB) } & --- & --- & 23 \\ & & & 0 . \\ \text { Unskilled (GB) } & --- & -- & 09 \\ \begin{array}{l}\text { Paternal work } \\ \text { characteristics }\end{array} & & & \end{array}$

$\begin{array}{cllll}\text { Employment } & 0.9 & 0.1 & & \\ \text { status (US) } & 8 & 4 & \ldots & -.- \\ & 10 . & 0.6 & 5 . & 0.9 \\ \text { Wages } & 30 & 9 & 80 & 1\end{array}$

Work hours

\begin{tabular}{|c|c|c|c|c|}
\hline \multicolumn{2}{|c|}{ Overtime (US) } & $\begin{array}{l}0.6 \\
3\end{array}$ & $\cdots$ & -- \\
\hline time $^{d}$ & Full & $\begin{array}{l}0.2 \\
9\end{array}$ & $\begin{array}{l}0 . \\
90\end{array}$ & \\
\hline time & Part & $\begin{array}{l}0.0 \\
7\end{array}$ & $\begin{array}{l}0 . \\
01\end{array}$ & \\
\hline & $\begin{array}{l}\text { Unempl } \\
\text { oyed/ } \\
\text { out of } \\
\text { the } \\
\text { labor } \\
\text { force } \\
\text { (GB) }\end{array}$ & & $\begin{array}{r}0 . \\
08 \\
8\end{array}$ & \\
\hline
\end{tabular}

Occupation

Professi

onal,

manager

ial,

technica

1 (and

also

military $\quad 0.2$

0.

in US)

31

Clerical, 0. service, 0

sales (US) 3

(US)

Craft $\quad 0.4$

Laborer 0.0

(US)

$9 \quad \cdots$ 





Child Cognition in the U.S. and Great Britain

Table 4. Unstandardized Coefficients and Standard Errors: PPVTR

\begin{tabular}{|c|c|c|c|c|c|c|c|c|c|c|c|c|}
\hline \multirow[b]{3}{*}{ Variables } & \multicolumn{4}{|c|}{ Model $1^{\mathrm{a}}$} & \multicolumn{4}{|c|}{ Model $2^{b}$} & \multicolumn{4}{|c|}{ Model $3^{b}$} \\
\hline & \multicolumn{2}{|c|}{ U.S. } & \multicolumn{2}{|c|}{ G.B. } & \multicolumn{2}{|c|}{ U.S. } & \multicolumn{2}{|c|}{ G.B. } & \multicolumn{2}{|c|}{ U.S. } & \multicolumn{2}{|c|}{ G.B. } \\
\hline & $b$ & $S E$ & $b$ & $S E$ & $b$ & $S E$ & $b$ & $S E$ & $b$ & $S E$ & $b$ & $S E$ \\
\hline \multicolumn{13}{|l|}{$\begin{array}{l}\text { Child } \\
\text { characteristic } \\
\text { s }\end{array}$} \\
\hline $\begin{array}{l}\text { Health } \\
\text { problems }\end{array}$ & $-7.26^{*}$ & $\begin{array}{l}1 . \\
59\end{array}$ & $-3.24^{*}$ & $\begin{array}{r}1.6 \\
8\end{array}$ & $\begin{array}{r}-6.71^{*} \\
* *\end{array}$ & $\begin{array}{l}1 . \\
56\end{array}$ & -3.874 & $\begin{array}{r}1.6 \\
6\end{array}$ & $\begin{array}{r}-6.88^{*} \\
* *\end{array}$ & $\begin{array}{r}1.5 \\
0\end{array}$ & $\begin{array}{r}-3.96^{*} \\
*\end{array}$ & $\begin{array}{r}1.6 \\
6\end{array}$ \\
\hline $\begin{array}{l}\text { Low birth } \\
\text { weight }\end{array}$ & $\begin{array}{r}-3.39^{*} \\
*\end{array}$ & $\begin{array}{l}1 . \\
19\end{array}$ & $-3.39^{*}$ & $\begin{array}{r}1.8 \\
4\end{array}$ & $\begin{array}{r}-3.17^{*} \\
*\end{array}$ & $\begin{array}{l}1 . \\
17\end{array}$ & $-3.54^{*}$ & $\begin{array}{r}1.7 \\
9\end{array}$ & $-2.35^{*}$ & $\begin{array}{r}1.1 \\
1\end{array}$ & $-3.55^{*}$ & $\begin{array}{r}1.8 \\
0\end{array}$ \\
\hline Male child & -.59 & $5 \dot{3}$ & .70 & .78 & -.56 & 52 & .93 & .76 & .04 & .51 & $1.53^{*}$ & .75 \\
\hline $\begin{array}{l}\text { Age of } \\
\text { child }\end{array}$ & $.06^{* * *}$ & 01 & -.21 & .17 & $.07^{* * *}$ & 01 & -.05 & .18 & $.07^{* * *}$ & .01 & -.04 & .18 \\
\hline \multicolumn{13}{|l|}{$\begin{array}{l}\text { Maternal } \\
\text { characteristic } \\
\mathrm{s}\end{array}$} \\
\hline $\begin{array}{l}\text { Minority } \\
\text { characteristic } \\
\text { s }\end{array}$ & $-7.75^{*}$ & 81 & -2.68 & $\begin{array}{r}3.3 \\
3\end{array}$ & $\begin{array}{r}-8.33^{*} \\
* *\end{array}$ & 82 & -4.63 & $\begin{array}{r}3.7 \\
6\end{array}$ & $-6.30^{*}$ & .81 & -4.07 & $\begin{array}{r}3.6 \\
8\end{array}$ \\
\hline Age & .00 & 15 & & & -.08 & 16 & & & -.11 & .15 & & \\
\hline Education & & & & & .24 & 17 & .05 & .12 & .11 & .14 & -.02 & .11 \\
\hline \multicolumn{13}{|l|}{$\begin{array}{l}\text { Education } \\
\text { track }\end{array}$} \\
\hline \multicolumn{13}{|l|}{$\begin{array}{l}\quad \text { College } \\
\text { prep } \\
\text { (omitted } \\
\text { category in } \\
\text { U.S.) }\end{array}$} \\
\hline  & .19 & 81 & & & .80 & 82 & & & 1.08 & .78 & & \\
\hline Vocational & .60 & $\begin{array}{l}1 . \\
10\end{array}$ & & & .95 & $\begin{array}{l}1 . \\
08\end{array}$ & & & 1.11 & $\begin{array}{r}1.0 \\
2\end{array}$ & & \\
\hline \multicolumn{13}{|l|}{$\begin{array}{l}\quad \text { Compreh } \\
\text { ensive } \\
\text { (omitted } \\
\text { category in } \\
\text { G.B.) }\end{array}$} \\
\hline & & & & 1.7 & & & & 1.7 & & & & 1.7 \\
\hline Grammar & & & 2.71 & 7 & & & $3.26^{*}$ & 5 & & & $3.48^{*}$ & 4 \\
\hline $\begin{array}{l}\text { Secondar } \\
\text { y modern }\end{array}$ & & & $-2.05^{*}$ & $\begin{array}{r}1.0 \\
0\end{array}$ & & & $-2.01^{*}$ & .99 & & & $-2.21^{*}$ & .97 \\
\hline $\begin{array}{c}\text { Other } \\
\text { school track }\end{array}$ & & & 1.84 & $\begin{array}{r}2.6 \\
8\end{array}$ & & & 1.70 & $\begin{array}{r}2.6 \\
6\end{array}$ & & & 2.20 & $\begin{array}{r}2.4 \\
2\end{array}$ \\
\hline
\end{tabular}


Child Cognition in the U.S. and Great Britain

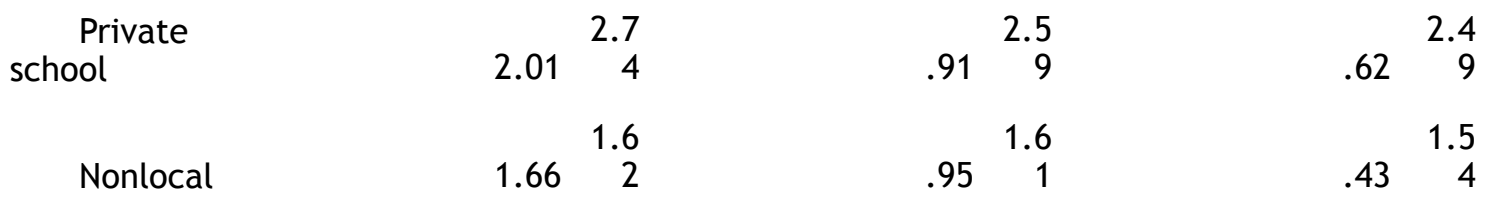

Cognitive

skills
AFQT81
$\begin{array}{rr}2.26^{* *} & 1 \dot{7} \\ * & 4\end{array}$
$1.83^{* *} \quad 18$
$\begin{array}{rr}1.57^{* *} & 1 \dot{7} \\ * & 9\end{array}$


nt in own learning


nal Educatio aspirations $\begin{array}{llllllllllll}.34 & 71 & 1.54^{*} & .70 & -.09 & 70 & .78 & .74 & -.28 & .67 & .42 & .72\end{array}$ Paternal characteristic $\mathrm{s}$

Age

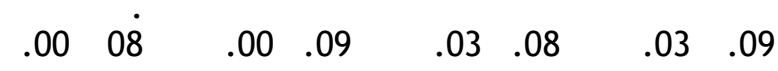

Education

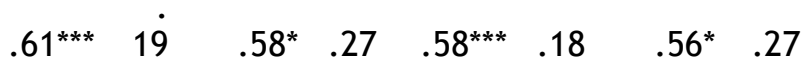

Family of origin

$\begin{array}{lrrrrrrrrrrrr}\text { Two-parent } & & & & 1.2 & & & & 1.3 & & \\ \text { family } & .20 & 69 & .40 & 8 & -.13 & 68 & .53 & 1 & -.58 & .65 & .55 & 5\end{array}$ Grandpare nt's

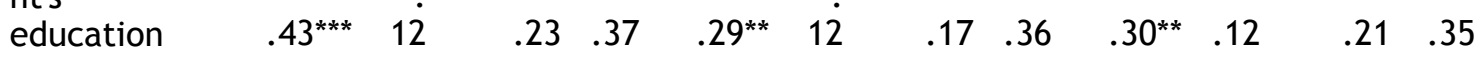




\author{
Maternal \\ work \\ characteristic \\ $\mathrm{s}$ \\ Employmen \\ t status
}

Wages

$\begin{array}{rrrrrrrrr}.18 & 90 & .56 & .99 & -1.06^{*} & .86 & -.28 & .99 \\ -.16 & 36 & .57 & .88 & -.26 & .35 & .43 & .82\end{array}$


Child Cognition in the U.S. and Great Britain

\begin{tabular}{|c|c|c|c|c|c|c|c|c|c|c|c|c|}
\hline \multirow[b]{3}{*}{ Variables } & \multicolumn{4}{|c|}{ Model $1^{\mathrm{a}}$} & \multicolumn{4}{|c|}{ Model $2^{\mathrm{b}}$} & \multicolumn{4}{|c|}{ Model $3^{b}$} \\
\hline & \multicolumn{2}{|c|}{ U.S. } & \multicolumn{2}{|c|}{ G.B. } & \multicolumn{2}{|c|}{ U.S. } & \multicolumn{2}{|c|}{ G.B. } & \multicolumn{2}{|c|}{ U.S. } & \multicolumn{2}{|c|}{ G.B. } \\
\hline & $b$ & $S E$ & $b$ & $S E$ & $b$ & $S E$ & $b$ & $S E$ & $b$ & $S E$ & $b$ & $S E$ \\
\hline $\begin{array}{r}\text { Maternal } \\
\text { work hours }\end{array}$ & & & & & & & & & & & & \\
\hline $\begin{array}{l}\quad \text { Full-time } \\
\text { (omitted } \\
\text { category) }\end{array}$ & & & & & & & & & & & & \\
\hline $\begin{array}{c}\text { Low } \\
\text { part-time }\end{array}$ & & & & & -.14 & $\begin{array}{l}1 . \\
48\end{array}$ & 1.58 & $\begin{array}{c}1 . \\
72\end{array}$ & 1.24 & $\begin{array}{r}1.4 \\
3\end{array}$ & 1.88 & $\begin{array}{r}1.6 \\
2\end{array}$ \\
\hline $\begin{array}{l}\text { Moderat } \\
\text { e part-time }\end{array}$ & & & & & -.11 & $\begin{array}{l}1 . \\
06\end{array}$ & -.28 & $\begin{array}{l}1 . \\
15\end{array}$ & 1.00 & $\begin{array}{r}1.0 \\
0\end{array}$ & .23 & $\begin{array}{r}1.1 \\
4\end{array}$ \\
\hline Overtime & & & & & .93 & $\begin{array}{l}1 . \\
19\end{array}$ & 2.31 & $\begin{array}{l}3 . \\
07\end{array}$ & .86 & $\begin{array}{r}1.1 \\
7\end{array}$ & 2.76 & $\begin{array}{r}3.0 \\
3\end{array}$ \\
\hline
\end{tabular}

Paternal
work
characteristi
CS

Employme
nt status

Wages

Paternal

work hours

Full-time

(omitted

category)

time $^{\text {Part- }}$

Overtime

Not in

labor force
$4.97^{*} \quad \begin{aligned} & 3 . \\ & 00\end{aligned} \quad 4.91 \quad 0$

$\begin{array}{llllllll}1.59^{* *} & 52 & .28^{* *} & 61 & 1.61^{* *} & .56 & .22 & .62\end{array}$ 


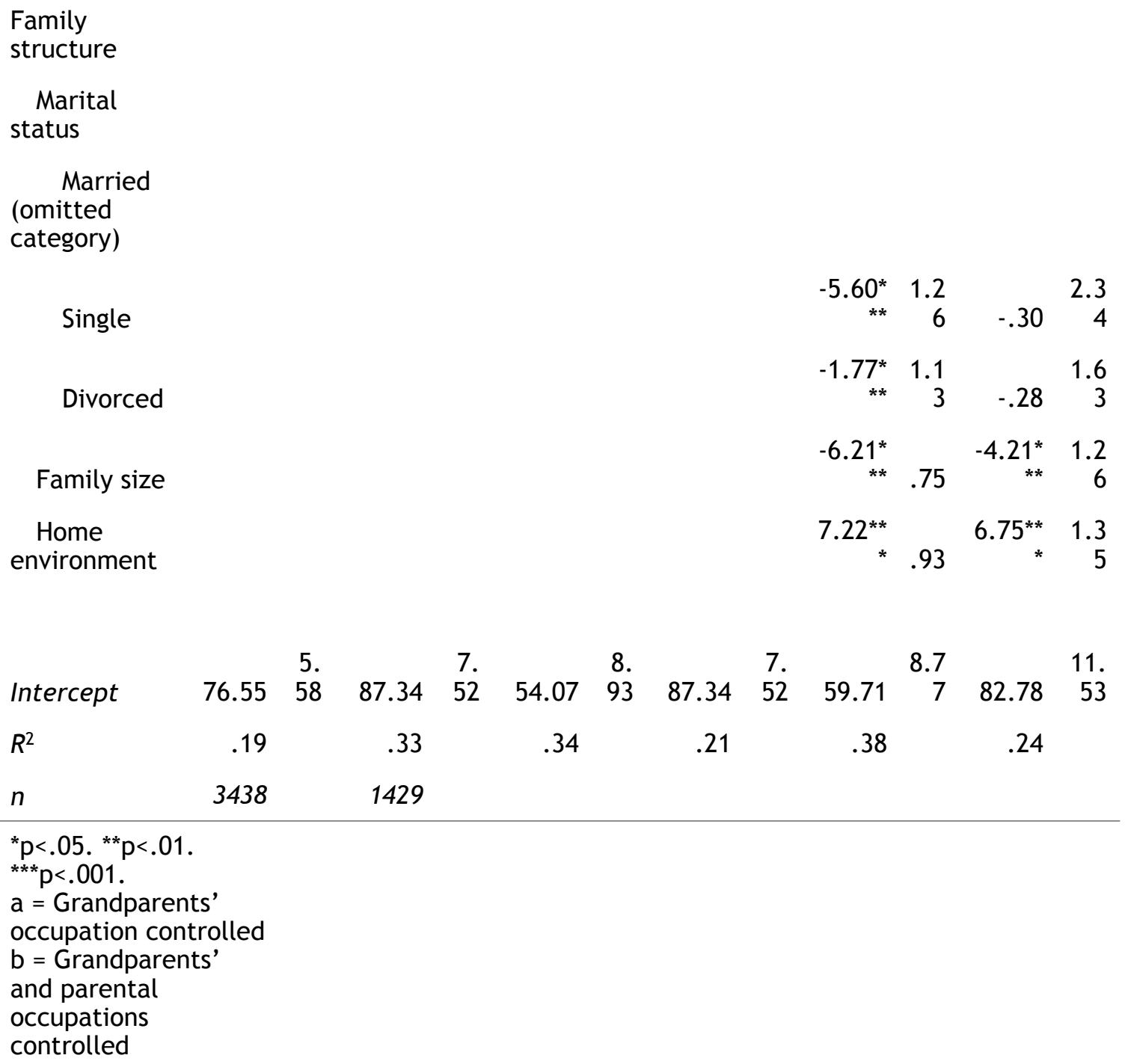


Child Cognition in the U.S. and Great Britain

Table 5. Unstandardized Coefficients and Standard Errors: Reading

\begin{tabular}{|c|c|c|c|c|c|c|c|c|c|c|c|c|c|c|c|c|}
\hline \multirow[b]{3}{*}{ Variables } & \multicolumn{4}{|c|}{ Model $1^{\mathrm{a}}$} & \multicolumn{4}{|c|}{ Model $2^{\mathrm{b}}$} & \multicolumn{4}{|c|}{ Model $3^{b}$} & \multicolumn{4}{|c|}{ Model $4^{\mathrm{b}}$} \\
\hline & \multicolumn{2}{|l|}{ U.S. } & \multicolumn{2}{|c|}{ G.B. } & \multicolumn{2}{|c|}{ U.S. } & \multicolumn{2}{|c|}{ G.B. } & \multicolumn{2}{|c|}{ U.S. } & \multicolumn{2}{|c|}{ G.B. } & \multicolumn{2}{|l|}{ U.S. } & \multicolumn{2}{|c|}{ G.B. } \\
\hline & $b$ & $S E$ & $b$ & $S E$ & $b$ & $S E$ & $b$ & $S E$ & $b$ & $S E$ & $b$ & $S E$ & $b$ & $S E$ & $b$ & $S E$ \\
\hline \multicolumn{17}{|l|}{$\begin{array}{l}\text { Child } \\
\text { characteristics }\end{array}$} \\
\hline $\begin{array}{c}\text { Health } \\
\text { problems }\end{array}$ & $\begin{array}{r}-7.49^{* *} \\
*\end{array}$ & $\begin{array}{r}1.2 \\
3\end{array}$ & $\begin{array}{r}-6.76^{* *} \\
*\end{array}$ & $\begin{array}{r}1.5 \\
6\end{array}$ & $\begin{array}{r}-7.11^{* *} \\
*\end{array}$ & $\begin{array}{r}1.2 \\
2\end{array}$ & $\begin{array}{r}-7.09^{* *} \\
*\end{array}$ & $\begin{array}{r}1.5 \\
5\end{array}$ & $\begin{array}{r}-7.19^{* *} \\
*\end{array}$ & $\begin{array}{r}1.1 \\
8\end{array}$ & $\begin{array}{r}-7.14^{* *} \\
*\end{array}$ & $\begin{array}{r}1.5 \\
7\end{array}$ & $\begin{array}{r}-5.22^{*} \\
* *\end{array}$ & $\begin{array}{r}1.0 \\
6\end{array}$ & $\begin{array}{r}-5.79^{*} \\
* *\end{array}$ & $\begin{array}{r}1.4 \\
5\end{array}$ \\
\hline $\begin{array}{l}\text { Low birth } \\
\text { weight }\end{array}$ & $-1.85^{*}$ & .97 & -2.05 & $\begin{array}{r}1.8 \\
6\end{array}$ & $-1.71^{*}$ & .97 & -2.26 & $\begin{array}{r}1.9 \\
1\end{array}$ & -1.21 & .94 & -2.32 & $\begin{array}{r}1.9 \\
1\end{array}$ & -.49 & .86 & -1.14 & $\begin{array}{r}1.7 \\
4\end{array}$ \\
\hline Male child & $\begin{array}{r}-3.35^{* *} \\
*\end{array}$ & .46 & $\begin{array}{r}-2.78^{* *} \\
*\end{array}$ & .80 & $\begin{array}{r}-3.33^{* *} \\
*\end{array}$ & .46 & $\begin{array}{r}-2.82^{* *} \\
*\end{array}$ & .81 & $\begin{array}{r}-2.90^{* *} \\
*\end{array}$ & .45 & $\begin{array}{r}-2.28^{* *} \\
*\end{array}$ & .81 & $\underset{* *}{-2.91^{*}}$ & .43 & $\begin{array}{r}-2.79^{*} \\
* *\end{array}$ & .77 \\
\hline Age of child & $-.03^{* * *}$ & .01 & -.18 & .17 & $-.02^{* * *}$ & .01 & -.03 & .18 & $-.02^{*}$ & .01 & -.02 & .17 & $-.04^{* * *}$ & .01 & -.01 & .17 \\
\hline \multicolumn{17}{|l|}{$\begin{array}{l}\text { Maternal } \\
\text { characteristics }\end{array}$} \\
\hline Minority & & & & 2.9 & & & & 3.0 & & & & 3.1 & & & & 3.6 \\
\hline characteristics & -.58 & .68 & 3.16 & 5 & $-1.13^{*}$ & .67 & 1.76 & 4 & .03 & .68 & 2.46 & 0 & $1.80^{* *}$ & .64 & 3.88 & 4 \\
\hline Age & .02 & .13 & & & -.06 & .13 & & & -.06 & .12 & & & -.02 & .12 & & \\
\hline Education & & & & & $.15^{*}$ & .09 & $.27^{*}$ & .11 & .07 & .07 & .20 & .11 & .04 & .06 & $.21^{*}$ & .11 \\
\hline \multicolumn{17}{|l|}{$\begin{array}{l}\text { Education } \\
\text { track }\end{array}$} \\
\hline \multicolumn{17}{|l|}{$\begin{array}{l}\text { College } \\
\text { prep (omitted } \\
\text { category in } \\
\text { U.S.) }\end{array}$} \\
\hline General & & & & & & & & & & & & & & & & \\
\hline track & -.99 & .66 & & & -.55 & .66 & & & -.35 & .65 & & & -.69 & .60 & & \\
\hline Vocational & .63 & .89 & & & .87 & .90 & & & .96 & .89 & & & .62 & .82 & & \\
\hline \multicolumn{17}{|l|}{$\begin{array}{l}\quad \text { Compre } \\
\text { hensive } \\
\text { (omitted } \\
\text { category in } \\
\text { G.B.) }\end{array}$} \\
\hline Gramma & & & & 1.6 & & & & 1.7 & & & & 1.7 & & & & 1.6 \\
\hline$r$ & & & 1.76 & 9 & & & 2.54 & 3 & & & 2.65 & 2 & & & 1.52 & 6 \\
\hline Seconda & & & & 1.1 & & & & 1.1 & & & & 1.1 & & & & 1.0 \\
\hline ry modern & & & -.58 & 2 & & & -.84 & 2 & & & -1.00 & 0 & & & -.28 & 3 \\
\hline Other & & & & 2.8 & & & & 2.9 & & & & 3.0 & & & & 3.0 \\
\hline school track & & & .39 & 2 & & & .73 & 9 & & & 1.04 & 2 & & & .27 & 4 \\
\hline Private & & & & 2.9 & & & & 2.8 & & & & 2.7 & & & & 2.5 \\
\hline school & & & 1.26 & 2 & & & .32 & 4 & & & .12 & 2 & & & -.04 & 5 \\
\hline & & & & 1.4 & & & & 1.5 & & & & 1.4 & & & & 1.2 \\
\hline Nonlocal & & & 2.30 & 8 & & & 1.65 & 0 & & & 1.26 & 1 & & & 1.15 & 8 \\
\hline \multicolumn{17}{|l|}{$\begin{array}{l}\text { Cognitive } \\
\text { skills }\end{array}$} \\
\hline & & & & & & 14 & & & & & & & & & & \\
\hline AFQT81 & $1.67^{* * *}$ & .13 & & & $1.32^{* * *}$ & 1 & & & $1.14^{* * *}$ & .14 & & & $.69^{* * *}$ & .13 & & \\
\hline Reading & & & & & & & & & & & & & & & & \\
\hline test & & & $.52^{* * *}$ & .09 & & & $.45^{* * *}$ & .09 & & & $.390^{* * *}$ & .08 & & & $.26^{* * *}$ & .08 \\
\hline
\end{tabular}


Child Cognition in the U.S. and Great Britain

\begin{tabular}{|c|c|c|c|c|c|c|c|c|c|c|c|c|c|c|c|c|}
\hline \multicolumn{17}{|l|}{ Math } \\
\hline test & & & .15 & .08 & & & .10 & .08 & & & .07 & .08 & & & .05 & .07 \\
\hline \multicolumn{16}{|l|}{ Investm } & \\
\hline learning & .37 & .38 & .19 & .63 & .26 & .37 & .23 & .62 & .19 & .37 & .11 & .61 & .17 & .34 & -.07 & .58 \\
\hline $\begin{array}{r}\text { Educatio } \\
\text { nal aspirations }\end{array}$ & .50 & .60 & $1.74^{* *}$ & .70 & .11 & .60 & 1.11 & .73 & .03 & .59 & .79 & .72 & .11 & .55 & .64 & .69 \\
\hline \multicolumn{17}{|l|}{$\begin{array}{l}\text { Paternal } \\
\text { characteristics }\end{array}$} \\
\hline Age & & & & & -.01 & .07 & .16 & .11 & .01 & .07 & $.18^{*}$ & .11 & .00 & .06 & $.17^{*}$ & .10 \\
\hline Education & & & & & $.42^{* *}$ & .17 & .27 & .24 & $.37^{* *}$ & .15 & .28 & .24 & .20 & .14 & .09 & .23 \\
\hline \multicolumn{17}{|l|}{$\begin{array}{l}\text { Family of } \\
\text { origin }\end{array}$} \\
\hline Two-parent & & & & 1.4 & & & & 1.4 & & & & 1.4 & & & & 1.3 \\
\hline family & -.30 & .58 & 1.47 & 5 & -.49 & .57 & 1.82 & 3 & -.66 & .55 & 1.80 & 1 & -.50 & .52 & 1.59 & 3 \\
\hline $\begin{array}{l}\text { Grandparent' } \\
\text { s education }\end{array}$ & .05 & .11 & .15 & .28 & -.06 & .11 & .11 & .28 & -.06 & .10 & .14 & .27 & -.14 & .10 & .06 & .24 \\
\hline
\end{tabular}

\begin{tabular}{|c|c|c|c|c|c|c|c|c|c|c|c|c|}
\hline \multicolumn{13}{|l|}{$\begin{array}{l}\text { Maternal work } \\
\text { characteristics }\end{array}$} \\
\hline \multicolumn{13}{|l|}{ Employment } \\
\hline status & .46 & .75 & -.33 & .97 & -.20 & .73 & -1.13 & .99 & .11 & .67 & -1.02 & .94 \\
\hline Wages & -.12 & .29 & -.22 & .73 & -.20 & .27 & -.31 & .73 & -.13 & .26 & -.48 & .78 \\
\hline \multicolumn{13}{|l|}{$\begin{array}{r}\text { Maternal } \\
\text { work hours }\end{array}$} \\
\hline \multicolumn{13}{|l|}{$\begin{array}{l}\quad \text { Full-time } \\
\text { (omitted } \\
\text { category) }\end{array}$} \\
\hline Low part- & & 1.1 & & 1.4 & & 1.1 & & 1.4 & & 1.1 & & 1.5 \\
\hline time & -.98 & 8 & .30 & 8 & -.26 & 8 & .53 & 9 & -.63 & 6 & -.15 & 8 \\
\hline Moderate & & & & 1.1 & & & & 1.1 & & & & 1.1 \\
\hline \multirow[t]{2}{*}{ part-time } & .16 & .95 & .48 & 6 & .83 & .90 & .97 & 5 & .54 & .82 & .87 & 2 \\
\hline & & & & 2.7 & & & & 2.6 & & & & 2.2 \\
\hline Overtime & .03 & .92 & -.27 & 5 & -.07 & .94 & .20 & 8 & -.28 & .93 & -.73 & 9 \\
\hline
\end{tabular}


Child Cognition in the U.S. and Great Britain

Paternal work

characteristics

Employment
status
Wages
Paternal
work hours

Full-time (omitted

category)

Part-time

Overtme

Not in

labor force

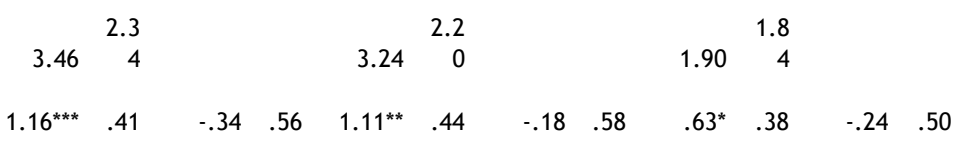

\begin{tabular}{|c|c|c|c|c|c|c|c|c|c|c|c|}
\hline & 1.2 & & 3.5 & & 1.2 & & 3.7 & & 1.1 & & 3.0 \\
\hline .67 & 6 & $-7.78^{*}$ & 8 & .82 & 2 & $-6.57^{*}$ & 4 & .70 & 3 & $-7.27^{*}$ & 4 \\
\hline$-1.33^{*}$ & .62 & & & -.77 & .67 & & & -.61 & .62 & & \\
\hline & & & 1.6 & & & & 1.6 & & & & 1.6 \\
\hline & & $-2.98^{*}$ & 7 & & & $-3.04^{*}$ & 8 & & & -2.21 & 7 \\
\hline
\end{tabular}

Family

structure (and

Control for

PPVTR)

Marital

status

Married(o

mitted

category)

Single

\begin{tabular}{|c|c|c|c|c|c|c|c|}
\hline & 1.1 & & 2.6 & & 1.0 & & 2.6 \\
\hline \multirow[t]{2}{*}{-1.85} & 3 & -2.80 & 9 & -.23 & 7 & -2.73 & 7 \\
\hline & & & 1.6 & & & & .5 \\
\hline-1.20 & .96 & -2.07 & 2 & -.68 & .91 & -1.98 & 2 \\
\hline $3.69^{* *}$ & & $-3.46^{* *}$ & 1.2 & $-1.94^{*}$ & & & .1 \\
\hline * & .62 & * & 4 & $* *$ & .57 & $-2.05^{*}$ & \\
\hline & & & 1.3 & $3.58^{* *}$ & & $4.01^{* *}$ & \\
\hline $5.61^{* * *}$ & .81 & $6.24^{* * *}$ & 5 & * & .76 & * & \\
\hline
\end{tabular}


Child Cognition in the U.S. and Great Britain

PPVTR

$\begin{array}{llll}.28^{* * *} & .02 & .33^{* * *} & .03\end{array}$

\begin{tabular}{lrrrrrrrr} 
Intercept & 102.42 & 96.26 & 88.86 & 91.09 & 93.21 & 94.11 & 76.42 & 66.59 \\
$R^{2}$ & .18 & .17 & .21 & .19 & .23 & .21 & .32 & .30 \\
$n$ & 3,438 & 1,429 & & & & & & \\
\hline
\end{tabular}

${ }^{*} \mathrm{p}<.05 .{ }^{* *} \mathrm{p}<.01 .{ }^{* * *} \mathrm{p}<$

001.

$\mathrm{a}=$ Grandparents'

occupation controlled

$\mathrm{b}=$ Grandparents' and

parental occupations

controlled

Table 6. Unstandardized Coefficients and Standard Errors: Math

\begin{tabular}{|c|c|c|c|c|c|c|c|c|c|c|c|c|c|c|c|c|}
\hline \multirow[b]{3}{*}{ Variables } & \multicolumn{4}{|c|}{ Model $1^{\mathrm{a}}$} & \multicolumn{4}{|c|}{ Model $2^{\mathrm{b}}$} & \multicolumn{4}{|c|}{ Model $3^{b}$} & \multicolumn{4}{|c|}{ Model $4^{\mathrm{b}}$} \\
\hline & \multicolumn{2}{|l|}{ U.S. } & \multicolumn{2}{|l|}{ G.B. } & \multicolumn{2}{|c|}{ U.S. } & \multicolumn{2}{|c|}{ G.B. } & \multicolumn{2}{|c|}{ U.S. } & \multicolumn{2}{|c|}{ G.B. } & \multicolumn{2}{|c|}{ U.S. } & \multicolumn{2}{|c|}{ G.B. } \\
\hline & $b$ & $S E$ & $b$ & $S E$ & $b$ & $S E$ & $b$ & $S E$ & $b$ & $S E$ & $b$ & $S E$ & $b$ & $S E$ & $b$ & SE \\
\hline \multicolumn{17}{|l|}{$\begin{array}{l}\text { Child } \\
\text { characteristics }\end{array}$} \\
\hline Health & $-7.16^{* *}$ & 1.1 & $-4.52^{* *}$ & 1.3 & $-6.89^{* *}$ & 1.1 & $-5.05^{* *}$ & 1.3 & $-6.92^{* *}$ & 1.1 & $-5.05^{* *}$ & 1.3 & $-5.04^{*}$ & & $-3.69^{*}$ & 1.1 \\
\hline problems & * & 4 & * & 7 & * & 2 & * & 3 & * & 0 & * & 2 & $* *$ & .95 & $* *$ & 4 \\
\hline Low birth & & & & 1.4 & & & & 1.4 & & & & 1.4 & & & & 1.3 \\
\hline weight & $-1.85^{*}$ & .85 & -2.17 & 5 & $-1.69^{*}$ & .87 & $-2.45^{*}$ & 3 & -1.31 & .85 & $-2.46^{*}$ & 8 & -.65 & .79 & -1.27 & 5 \\
\hline Male child & .01 & .42 & .16 & .68 & .01 & .42 & .38 & .68 & .38 & .42 & .75 & .69 & .37 & .39 & .23 & .64 \\
\hline Age of child & .00 & .01 & $-.68^{* * *}$ & .14 & .00 & .01 & $-.59^{* * *}$ & .14 & .01 & .01 & $-.59^{* \star *}$ & .14 & $-.015^{*}$ & .01 & $-.58^{* * *}$ & .13 \\
\hline \multicolumn{17}{|l|}{$\begin{array}{l}\text { Maternal } \\
\text { characteristics }\end{array}$} \\
\hline Minority & $-3.13^{* *}$ & & & 3.6 & $-3.42^{* *}$ & & & 3.4 & $-2.57^{* *}$ & & & 3.4 & & & & 3.1 \\
\hline characteristics & * & .57 & $6.92^{*}$ & 1 & * & .57 & $6.07^{*}$ & 6 & * & .57 & 6.52 & 4 & -.88 & .53 & $7.97^{* *}$ & 7 \\
\hline Age & -.03 & .11 & & & -.10 & .12 & & & -.10 & .11 & & & -.07 & .11 & & \\
\hline Education & & & & & .03 & .10 & .12 & .10 & -.03 & .08 & & & -.06 & .08 & .09 & .08 \\
\hline \multicolumn{17}{|l|}{$\begin{array}{l}\text { Education } \\
\text { track }\end{array}$} \\
\hline \multicolumn{17}{|l|}{$\begin{array}{l}\text { College } \\
\text { prep (omitted } \\
\text { category in } \\
\text { U.S.) }\end{array}$} \\
\hline General & & & & & & & & & & & & & & & & \\
\hline track & $-1.38^{*}$ & .63 & & & -.98 & .62 & & & -.76 & .60 & & & $-1.07^{*}$ & .55 & & \\
\hline Vocational & -.70 & .76 & & & -.40 & .75 & & & -.24 & .73 & & & -.53 & .68 & & \\
\hline \multicolumn{17}{|l|}{$\begin{array}{l}\quad \text { Compre } \\
\text { hensive } \\
\text { (omitted } \\
\text { category in } \\
\text { G.B.) }\end{array}$} \\
\hline Gramma & & & & 1.2 & & & & 1.2 & & & & 1.2 & & & & 1.1 \\
\hline$r$ & & & -1.21 & 2 & & & -.66 & 8 & & & -.51 & 6 & & & -1.64 & 8 \\
\hline $\begin{array}{l}\text { Seconda } \\
\text { ry modern }\end{array}$ & & & -.13 & .94 & & & -.18 & .91 & & & -.26 & .90 & & & .47 & .82 \\
\hline Other & & & & 3.6 & & & & 3.6 & & & & 3.5 & & & & 3.3 \\
\hline school track & & & 1.54 & 4 & & & 1.99 & 2 & & & 2.31 & 5 & & & 1.54 & 8 \\
\hline
\end{tabular}


Child Cognition in the U.S. and Great Britain

\begin{tabular}{|c|c|c|c|c|c|}
\hline \multirow{2}{*}{$\begin{array}{l}\text { Private } \\
\text { school }\end{array}$} & & 3 & & & 2.3 \\
\hline & 3.03 & 2 & 2.24 & 7 & 2.20 \\
\hline & & 3 & & 3 & \\
\hline Nonlocal & . 15 & 3 & -.40 & 0 & -.64 \\
\hline
\end{tabular}

Cognitive

skills
AFQT81 $1.50^{* * *} \quad .12$
$1.29^{* * *} .13$
$1.12^{* * *} .13$
$.69^{* * *} \quad .12$

test Reading

$.33^{* * *} \quad .08$

$.27^{* * *} \quad .08$

$.23^{* * *} \quad .07$

$\begin{array}{ll}.10 & .07\end{array}$

Math

test

$.30^{* * *} \quad .06$

$.26^{* * *} \quad .07$

$.24^{* * *} \quad .07$

$.23^{* * *} \quad .06$

ent in own

learning

$\begin{array}{lllllllllllllllll}.01 & .33 & -.11 & .52 & -.09 & .33 & -.01 & .52 & -.15 & .32 & -.08 & .51 & -.16 & .30 & -.26 & .46\end{array}$

Educatio

nal aspirations

$\begin{array}{llllllllllllllll}.06 & .51 & .88 & .62 & -.12 & .52 & .38 & .64 & -.22 & .51 & .15 & .63 & -.15 & .47 & .00 & .59\end{array}$

Paternal

characteristics

Age

Education

$\begin{array}{rrrrrrrrrrrr}-.01 & .05 & .00 & .10 & .00 & .05 & .02 & .09 & .00 & .05 & .01 & .09 \\ .51^{* * *} & .14 & .18 & .22 & .48^{* * *} & .13 & .15 & .22 & .32^{* *} & .12 & -.04 & .20\end{array}$

Family of

origin

\begin{tabular}{|c|c|c|c|c|c|c|c|c|c|c|c|c|c|c|c|}
\hline Two-parent & & & & 1.2 & & & & 1.2 & & & & 1.1 & & & \\
\hline family & -.23 & .50 & -.54 & 0 & -.34 & .49 & -.31 & 2 & -.47 & .48 & -.35 & 7 & -.31 & .45 & -.57 \\
\hline $\begin{array}{l}\text { Granapare } \\
\text { s education }\end{array}$ & .11 & .09 & .12 & .25 & .00 & .09 & .08 & .25 & .00 & .09 & .10 & .24 & -.07 & .08 & .02 \\
\hline
\end{tabular}

Maternal work

characteristics

Employment

status

Wages

\begin{tabular}{|c|c|c|c|c|c|c|c|c|c|}
\hline $.16 \quad .64$ & & & -.60 & .62 & .95 & .85 & -.30 & .57 & 1.06 \\
\hline .25 & .32 & .60 & -.04 & .25 & .30 & .59 & .03 & .22 & .13 \\
\hline
\end{tabular}

Maternal work hours 
Child Cognition in the U.S. and Great Britain

\begin{tabular}{|c|c|c|c|c|c|c|c|c|c|c|c|c|}
\hline $\begin{array}{l}\quad \text { Full-time } \\
\text { (omitted } \\
\text { category) }\end{array}$ & & & & & & & & & & & & \\
\hline Low part- & & 1.0 & & 1.2 & & 1.0 & & 1.2 & & & & 1.2 \\
\hline time & $1.81^{*}$ & 6 & 1.49 & 3 & $2.26^{*}$ & 5 & 1.77 & 4 & $1.90^{*}$ & .95 & 1.08 & 2 \\
\hline Moderate & & & & & & & & 1.0 & & & & \\
\hline part-time & -.34 & .77 & -.17 & .99 & .07 & .75 & .17 & 0 & -.21 & .69 & .07 & .93 \\
\hline & & & & 2.6 & & & & 2.6 & & & & 2.1 \\
\hline Overtime & -.44 & .85 & .01 & 2 & -.52 & .85 & .37 & 6 & -.71 & .81 & -.57 & 8 \\
\hline
\end{tabular}

Paternal work characteristics Employment status

Wages

Paternal work hours Full-time (omitted category)

\section{Part-time}

Overtime

Not in labor force

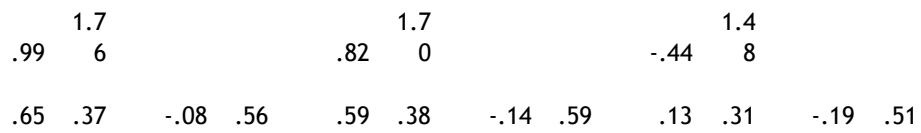

\begin{tabular}{|c|c|c|c|c|c|c|c|c|c|c|c|}
\hline & & & .5 & & & & .6 & & & & 3.1 \\
\hline-.16 & .99 & -2.86 & 2 & -.04 & .95 & -2.34 & 6 & -.14 & .85 & -3.05 & 4 \\
\hline-.26 & .55 & & & .21 & .59 & & & .38 & .54 & & \\
\hline & & & .4 & & & & .4 & & & & 1.4 \\
\hline & & -1.36 & 7 & & & -1.05 & 9 & & & -.21 & 0 \\
\hline
\end{tabular}


Child Cognition in the U.S. and Great Britain



